\title{
The synthesis of selected phase II metabolites $-O$-glucuronides and sulfates of drug development candidates
}

\author{
Jens Atzrodt,* Volker Derdau, Wolfgang Holla and Martin Sandvoss \\ Sanofi-Aventis Deutschland GmbH, R\&D, SCP Disposition, Safety \& Animal Research (DSAR), \\ Drug Disposition (DD), Isotope Chemistry \& Metabolite Synthesis (ICMS), G876, 65926 \\ Frankfurt/Höchst, Germany. \\ E-mail: Jens.Atzrodt@sanofi.com
}

Dedicated to Rainer Beckert on the occasion of his $60^{\text {th }}$ anniversary

\begin{abstract}
We have summarized methods for the preparation of phase II metabolites which have proven to be successful in our laboratory for the synthesis of selected $O$-glucuronides and sulfates of recent drug development candidates. The syntheses of the $O$-glucuronides AVE0897 $O$-acylglucuronide 7, AVE2268 $O$-glucuronide 12, SAR7226 $O$-glucuronide 21 and the preparation of the sulfates 28 of AVE2268 and MDL107292 33 are described in detail. Analytical aspects related to phase II metabolites and specific chromatographic methods of very polar compounds are discussed.
\end{abstract}

Keywords: Phase II metabolites, glucuronides, acyl glucuronides, sulfates, metabolite analysis

\section{Table of Contents}

1. Introduction

2. $O$-Glucuronides

2.1-O-Acyl glucuronides

2.2 1-O-Alkyl and 1-O-Aryl glucuronides

3. Sulfates

4. General aspects of the analysis of phase II-metabolites

4.1 Acyl glucuronide of AVE0897 (7)

4.2 Sulfate conjugate MDL107292 (33)

5. Conclusions

6. Experimental section 


\section{Introduction}

Drugs administered to the body typically undergo biphasic metabolic transformation to facilitate elimination from the body by increased water solubility. ${ }^{1}$ During phase I metabolism (functionalization) polar functionalities are either introduced or unmasked e.g. by oxidation, hydrolysis, dealkylation or fragmentation. If the phase I metabolites are sufficiently polar, they may be readily excreted via bile or urine. However, many phase I metabolites are not eliminated rapidly and undergo subsequent phase II transformations in which an endogenous substrate (e.g. glycine, sulfate, or glucuronic acid) interacts with the newly formed functional group to give even more polar conjugates. ${ }^{2}$

Although, in general, metabolism is a detoxification process, phase I metabolism can, in some instances, lead to a chemically reactive or pharmacologically active molecule or even turn a nontoxic compound into a poisonous metabolite. ${ }^{3}$ In addition, safety assessments may also be needed for phase II metabolites if the conjugation results in the formation of chemical structures (e.g. acyl glucuronides) known to be linked to a potential toxicity. ${ }^{4}$

In order to assess potential safety concerns related to drug metabolism, the US Food and Drug Administration (FDA) has recently published the industry guidance "Safety Testing of Drug Metabolites" ${ }^{, 5}$ which requires identification ${ }^{6}$ of metabolite profiles and further toxicological testing $^{7}$ for those metabolites formed at greater than $10 \%$ of parent drug systemic exposure at steady state. ${ }^{8}$ In the guidance the FDA acknowledges difficulties associated with the synthesis of specific drug metabolites, but nevertheless considers the identification and evaluation of the potential toxicity to be important to ensure patient safety. Consequently, there is a high demand for efficient, robust, and reliable drug metabolite syntheses through from milligram to gram scale. For a drug development candidate syntheses of several different metabolites can be required, not only for pharmacological activity determination and toxicological testing but also for use as authentic samples for: structural proof by NMR, recovery in LC-MS based assays, for protein and receptor binding as well as transporter studies. ${ }^{9}$ The latter may require the preparation of a radioactively labeled metabolite. Additionally, stable isotope labeling might be necessary for the validation of bioanalytical LC-MS/MS assays if a relevant metabolite needs to be monitored in clinical studies. In cases where the exposure of a metabolite in animal studies does not approach human exposure (so-called disproportionate metabolites ${ }^{10}$ ) or when a metabolite is exclusively formed in humans (human unique metabolite ${ }^{11}$ ) large quantities up to several kilograms may be required for nonclinical toxicological studies.

In principle, metabolite synthesis may be accomplished either by chemical or biological means and both approaches are pursued in the pharmaceutical industry, the choice being dictated by case-specific factors. In particular, the preparation of very polar, conjugated phase II metabolites can have some very challenging aspects, e.g. synthesis, purification, stability, isolation and analysis. Biotechnological approaches for phase II metabolite production, e.g. UGT (uridine diphosphoglucuronosyltransferase) mediated glucuronide preparation $^{12}$ have been recently reviewed together with whole-cell biotransformation processes for phase I metabolite 
synthesis. ${ }^{13}$ In this paper we would like to summarize specific chemical methods developed for the preparation of phase II metabolites and thereby specifically focus on recent work of our group in this area.

\section{2. $O$-Glucuronides}

$O$-Glucuronides can be divided into three classes: alkyl, aryl, and acyl. 1-O-alkyl and -aryl glucuronides generally exhibit good chemical stability. For their synthesis which is sometimes more difficult than the preparation of the corresponding glucosides, acyl and ether protected bromides, chlorides, and imidates are the most common glucuronyl donors. ${ }^{14}$

1- $O$-acyl glucuronides are prone to hydrolysis and rearrangement. In addition to the above mentioned donors, the use of 1-hydroxy sugars has gained increasing popularity. Due to stability issues final deprotection step(s) protective groups which can be removed chemoselectively under mild reaction conditions (e.g. Aloc- or silyl) are becoming increasingly important. ${ }^{14}$

\subsection{1-O-Acyl glucuronides}

Acyl glucuronidation is a major phase II metabolic path for carboxylic acids which can have important toxicological implications for a drug for two reasons: the potential pharmacological activity of the acyl glucuronide and its chemical reactivity. ${ }^{4,15}$ This reactivity is due to the electrophilic nature of the acyl glucuronide and can result in: spontaneous hydrolysis to the parent aglycone, $\mathrm{pH}$-dependent intramolecular acyl migration ${ }^{16}$ as well as transacylation and glycation reactions with proteins, nucleic acids and other nuclephilic components. ${ }^{17}$ The assessment of the potential safety risks associated with acyl glucuronides often requires detailed pharmacokinetic analysis including determination of clearance, systemic exposure and protein binding and consequently in many cases synthesis of metabolite reference material is required.

For all these reasons our group recently received a request for the synthesis of the $1-\beta-O$-acyl glucuronide 7 of the highly potent, orally active mixed peroxisome proliferator-activated receptor (PPAR) $\alpha / \gamma$ agonist AVE0897 (1) developed for treatment of type 2 diabetes. Due to its dual activity, $\mathbf{1}$ has the potential to improve both glucose control and the atherogenic lipid profile of type 2 diabetics or insulin-resistant patients.

Anomeric stereocontrol is an important aspect in the synthesis of acyl glucuronides, in order to obtain the single $\beta$-anomer observed in-vivo. ${ }^{18}$ Direct acylation of unprotected glucuronic acid with the $N$-acylimidazoles of carboxylic acids has been restricted to some specific examples, e.g. retinoic acid and reported yields are relatively low. ${ }^{19}$ Alternatively fully protected glucuronyl donors can be conjugated with the carboxylic acid using either Mitsunobu conditions ${ }^{20}$ or the trichloroacetimidate method. ${ }^{21}$ However, multi-step manipulations are required for the preparation of the protected glucuronyl donor $^{22}$ and often anomeric mixtures of the 1-Oacylglucuronide are observed with this method. 


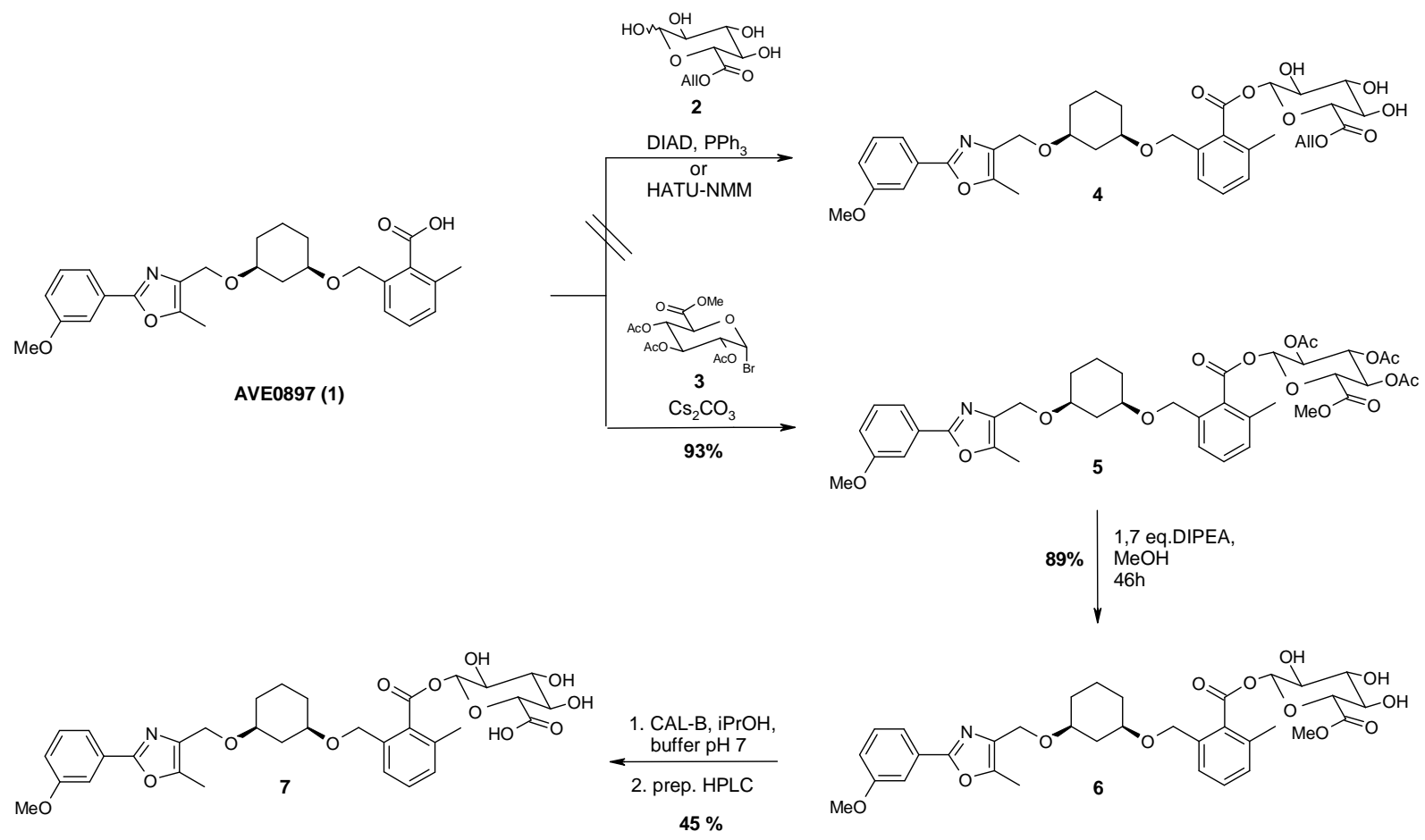

Scheme 1. Synthesis of 1- $\beta$-O-acyl glucuronide of AVE0897 (7).

Usually much better $\beta / \alpha$-ratios are obtained by acylation of allyl glucuronate 2 under Mitsunobu conditions ${ }^{23}$ or the HATU- coupling procedure ${ }^{24}$ and therefore, this approach was our first choice for the preparation of protected glucuronate 4 (Scheme 1). Unfortunately, all attempts to achieve coupling under Mitsunobu conditions, by varying coupling reagents e.g. HATU, EDC/HOBT and bases such as DMAP, NMM, DBU, $\mathrm{Cs}_{2} \mathrm{CO}_{3}$ or even via the acid chloride $^{25}$ of AVE0897 failed, most probably due to the sterically hindered position of the carboxyl function. A model reaction with benzoic acid under HATU/DMAP coupling conditions provided the desired glucuronidation product, whereas the same reaction with 2,6dimethylbenzoic acid failed to work at all.

Selective 1- $\beta$ - $O$-acyl glucuronide formation has been also reported under classical KoenigsKnorr conditions ${ }^{26}$ or in the presence of $\mathrm{Cs}_{2} \mathrm{CO}_{3}{ }^{27}$ using commercially available methyl 2,3,4-tri$O$-acetyl-1-bromo-1-deoxy- $\alpha$-D-glucopyranuronate 3 . In fact, under the latter conditions both the model substrate 2,6-dimethylbenzoic acid and AVE0897 were converted to their corresponding protected glucuronides and in this way 5 was obtained in very good yield (80\%) as the pure $\beta$ anomer. $^{28}$

The next challenge in acyl glucuronide syntheses is the selective removal of the protecting groups without affecting the 1- $\beta$ - $O$-acyl linkage. Recently, a sequential enzyme-catalyzed chemoselective hydrolysis of the $O$-acetyl groups using lipase AS amino (LAS) followed by methyl ester cleavage with PLE (porcine liver esterase) has been reported. ${ }^{27,29}$ However, in spite of varying incubation conditions, buffer, co-solvent and enzyme concentrations the LAS/PLE 
method could not be successfully applied to the deprotection of 5. Selective deacetylation was, however, achieved with Hünig's base in methanol at room temperature. ${ }^{30}$ Since acyl-migration and epimerization at the anomeric carbon of $\mathbf{6}$ could be excluded by NMR analysis, other reported saponification methods e.g. $\mathrm{NH}_{3} / \mathrm{MeOH},{ }^{31}$ Zemplén deacylation ${ }^{32}$ (catalytic amounts of $\mathrm{MeONa}$ in $\mathrm{MeOH}$ ) or titanate-mediated transesterification ${ }^{33}$ were not attempted. Finally the methyl ester group in $\mathbf{6}$ was removed by an enzymatic cleavage catalyzed by Candida antarctica lipase (CAL-B) in excellent yield. The crude product was purified by preparative HPLC to obtain 1- $\beta$-O-acyl glucuronide 7 of AVE 0897 in $37 \%$ overall yield starting from AVE 08971. The same sequence was also applied for the synthesis of stable isotope labeled [methoxy${ }^{13} \mathrm{C}^{2} \mathrm{H}_{3}$ ]-7 as well as [carboxyl- ${ }^{14} \mathrm{C}$ ]-7 starting from labeled parent drug [methoxy- $\left.{ }^{13} \mathrm{C}^{2} \mathrm{H}_{3}\right]-\mathbf{1}$ and [carboxyl- $\left.{ }^{14} \mathrm{C}\right]-\mathbf{1}$, respectively.

\section{1-O-Alkyl and 1-O-Aryl glucuronides}

For the synthesis of $O$-aryl and $O$-alkyl glucuronides there are basically two approaches:

(1) Glucuronidation by employing a glucuronyl donor and

(2) Synthesis of the corresponding glucoside followed by oxidation of the 6-OH group to the acid function.

Glucuronidation methods have their parallel in the synthesis of glucosides, but for a given aglycone, glucuronidation needs greater activation. Acyl-protected trichloroacetimidates and bromo sugars are the most often used glucuronyl donors. Both can be synthesized in 3 to 4 steps starting from commercially available D-glucurono-6,3-lactone. ${ }^{34,35}$

For the second synthetic strategy, oxidation of the primary hydroxy group to the acid, a number of reagents are known, e.g. TEMPO/ $\mathrm{NaOCl}^{36}$ or the Dess-Martin periodinane giving the aldehyde, followed by $\mathrm{NaClO}_{2}$ treatment.

For the synthesis of $O$-glucuronide metabolite 12 we initially envisaged a one step synthesis approach starting from parent drug AVE2268 8. ${ }^{37}$ AVE2268, 8 is a SGLT inhibitor and was developed as a potential treatment for type 2 diabetes. Firstly, we tried to directly oxidize the glucoside moiety to afford the corresponding glucuronide. All attempts using reported methods, e.g. $\mathrm{KMnO}_{4}, \mathrm{SeO}_{2}, \mathrm{PtO}_{2} / \mathrm{O}_{2}$ TEMPO/NaOCl/Oxone, ${ }^{36}$ peroxidases, etc. failed. Additionally, all trials to bring about transacetalisation of AVE2268 8 to 12 by treatment with glucuronic acid in the presence of an acid (e.g. p-toluenesulfonic acid) were unsuccessful. Application of an orthogonal protecting group strategy finally allowed the selective oxidation at the C6-position. This route presented several challenges to be overcome (Scheme 2). Any traces of acid had to be avoided in order to prevent acetyl migration during the oxidation step. Attempts to oxidize the acetyl-protected AVE2268, 9 directly to the acid yielded only starting material or decomposition products. Therefore the oxidation was carried out stepwise. In the first oxidation step using the Dess-Martin periodinane, a very weak base had to be used in order to prevent double bond formation by elimination of acetic acid, and the second oxidation had to be performed 
immediately on the unstable intermediate aldehyde. Final cleavage of the acetyl groups with sodium methoxide led to $\mathbf{1 2}$ after 6 steps in $68 \%$ overall yield. ${ }^{38}$

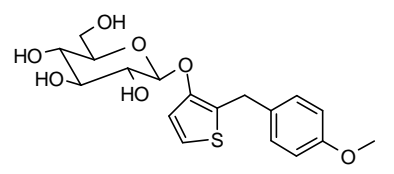

AVE2268 8

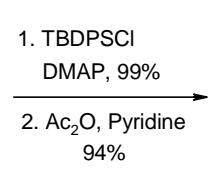

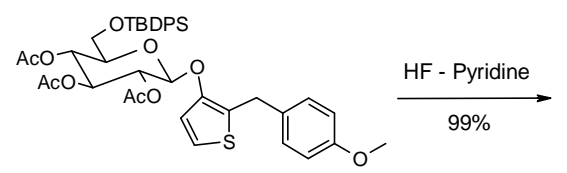

9

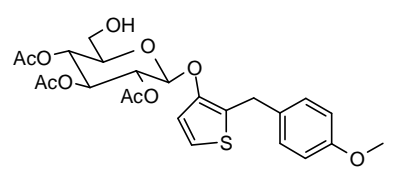

10

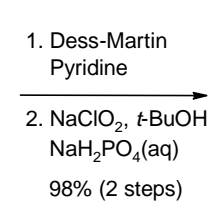

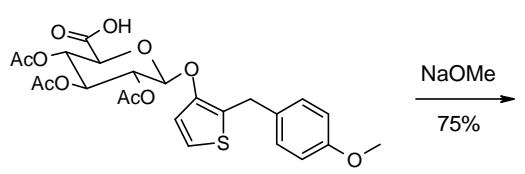

11

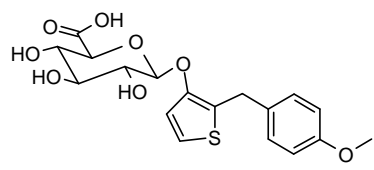

12

Scheme 2. Synthesis of $O$-glucuronide of AVE2268 (12).

For the synthesis of SAR7226 $O$-glucuronide 21, we initially investigated the glucuronidation of unprotected SAR7226 (13) (Scheme 3). It was hoped to predominantly derivatize the more reactive, primary 6-hydroxy group, but both the reaction of 13 with trichloroacetimidate 14a catalyzed by TMSOTf and the $\mathrm{Ag}_{2} \mathrm{CO}_{3}$-mediated reaction with bromo sugar $\mathbf{1 4 b}$ resulted in only a negligible formation of glucuronides.

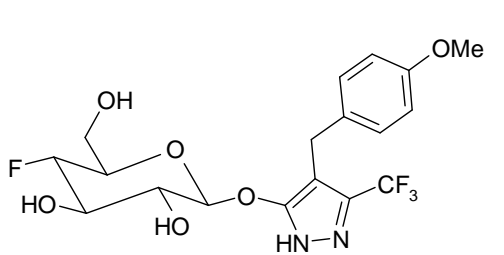

13

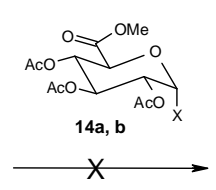

14a: $\mathrm{X}=\alpha-\mathrm{O}-\mathrm{C}(=\mathrm{NH})-\mathrm{CCl}_{3}$ 14b: $\alpha-\mathrm{Br}$

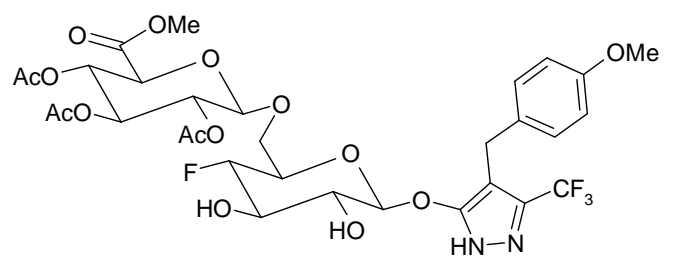

15

Scheme 3. Attempts to glucuronidate unprotected SAR7226 (13).

Starting from the fully protected SAR7226 derivative 16, synthesized from 1-chloromethyl4-methoxy-benzene, 4,4,4-trifluoro-3-oxo-butyric acid ethyl ester, and benzylhydrazine the synthesis of SAR7226 $O$-glucuronide 21 required 7 linear steps followed by a final purification by preparative HPLC (Scheme 4). 

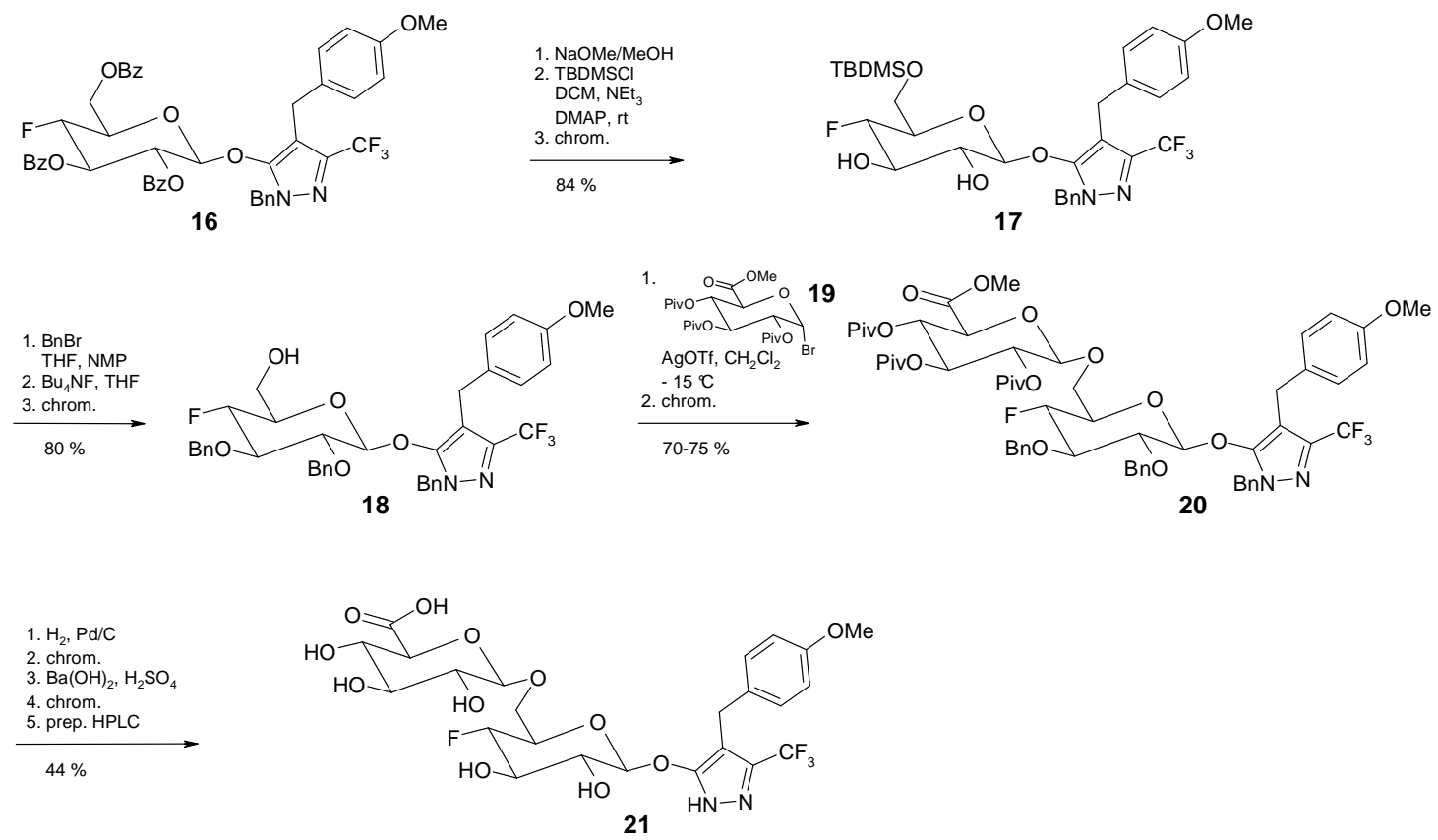

Scheme 4. Synthesis of SAR7226 metabolite 21.

$N$-benzyl-, $O$-benzoyl-protected SAR7226 derivative 16 was debenzoylated using sodium methoxide in methanol at ambient temperature, followed by the selective protection of the 6hydroxy group with TBDMS chloride in dichloromethane in the presence of triethylamine and catalytic amounts of DMAP. Benzylation of $\mathbf{1 7}$ employing benzyl bromide and sodium hydride in NMP, and subsequent deprotection of the 6-hydroxy group with TBAF $\left(\mathrm{Bu}_{4} \mathrm{NF}\right)$ in THF gave the desired glycosyl acceptor 18 in $67 \%$ overall yield. The glucuronidation step was studied with commercially available acetyl- ${ }^{39}$ and benzoyl- ${ }^{40}$ protected trichloroimidates as well as with acetyl-, benzoyl-, and pivaloyl-protected bromides. ${ }^{41}$ The pivaloyl-protected bromide 19, which turned out to be more stable than the corresponding acetyl compound $\mathbf{1 4 b}$, is known to exhibit a lower tendency towards ortho ester formation and gave the best yields of the desired 1- $\beta$ glucuronide 20. AgOTf-catalyzed reaction of glucuronyl donor 19 with the partially protected drug candidate 18 in dichloromethane at $-15^{\circ} \mathrm{C}$ gave 20 in $70-75 \%$ yield after chromatography. Debenzylation was achieved by hydrogenation in $85 \%$ yield. Hydrolysis of the ester groups was a critical step: depending on the reaction conditions a significant amount of $\alpha_{y} \beta$-unsaturated carboxylic ester $\mathbf{2 2}$ and/or acid $\mathbf{2 3}$ was observed (Scheme 5). 


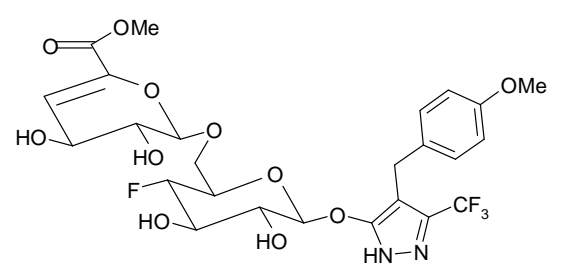

22

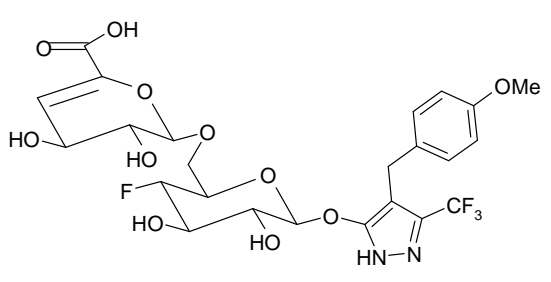

23

Scheme 5. By-products resulting from elimination during basic hydrolysis.

Good results were achieved by using $\mathrm{Ba}(\mathrm{OH})_{2}{ }^{42}$ for both the hydrolysis of the methyl ester group and the cleavage of the pivaloyl groups. The use of $\mathrm{Ba}(\mathrm{OH})_{2}$ also simplified the work-up: after complete deprotection the reaction mixture was neutralized by addition of an equivalent of sulfuric acid followed by filtration of the resultant sparingly soluble salts. Chromatography on silica gel in dichloromethane/methanol 95:5 and final purification via preparative HPLC gave the desired $O$-glucuronide 9 in about $21 \%$ overall yield.

\section{Sulfates}

Sulfation, like glucuronidation, is a major reaction in phase II drug and xenobiotic metabolism and was initially identified in the mid- $19^{\text {th }}$ century. The reaction involves sulfotransferases (SULTs) which catalyse the transfer of a sulfonate group from 3'-phosphoadenosine 5'phosphosulfate (PAPS) to either a hydroxyl moiety to form a sulfate or to an amine to form a sulfonamide. Sulfate conjugation is, like most metabolism reactions, an inactivation process since most conjugates are biologically inactive owing to the presence of the bulky charged sulfonate group. The sulfonate group has a $\mathrm{pKa}$ of approximately 2 and is ionized at physiological $\mathrm{pHs}$ which results in rapid excretion of the sulfonates via kidneys and liver. ${ }^{43}$

As described before some of these metabolites are of interest in drug development due to unknown pharmacological or toxicological activity. The syntheses and analytics of sulfates have their own unique challenges. However, only a few examples using enzymatic or chemical examples have been reported. ${ }^{44}$ At present, the most convenient synthetic method for the preparation of sulfates applies sulfur trioxide tertiary amine complexes as the sulfation reagent. ${ }^{45}$

Scheme 6 shows the synthesis of the sulfate metabolite $\mathbf{2 8}$ of AVE2268 8. 4Hydroxybenzoic acid $\mathbf{2 4}$ was alkylated with allylbromide and converted to the corresponding acyl chloride 25. Friedel-Crafts acylation with 3-methoxy thiophene and selective methyl ether cleavage resulted in ketone 26. Carbonyl reduction was followed by the successful formation of the allyl-protected sulfate 27. After initial unsuccessful attempts to remove the allyl-group we surprisingly succeeded by combining the conditions of Hara ${ }^{46}$ and $\mathrm{Zhu}^{47}$ with the addition of catalytic amounts of $\mathrm{NaBH}_{4}$. Accordingly 27 was heated in the presence of $\mathrm{NaBH}_{4}$-activated $\mathrm{Pd} / \mathrm{C}$ catalyst in $\mathrm{MeOH} / \mathrm{KOH}$ under microwave conditions in a closed vial for $80 \mathrm{~min}$. We found that only the combination of high temperature, strong basic conditions and $\mathrm{NaBH}_{4}$-activated $\mathrm{Pd} / \mathrm{C}$ catalyst gave reasonable yields in the deprotection of $\mathbf{2 7}$. It is worthy of note that our first 
synthesis attempt using a $O$-benzyl protecting group failed because we were unable to remove the protecting group in the last reaction step.

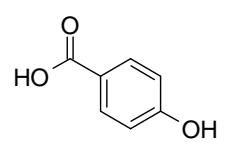

24
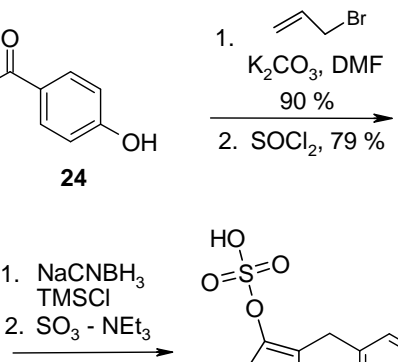

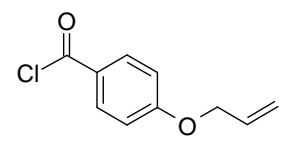

25

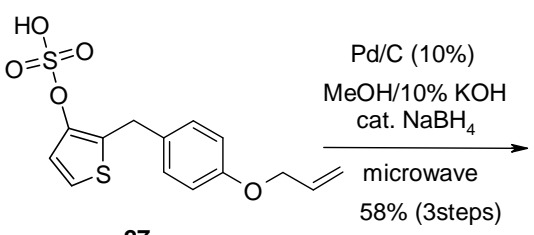

27

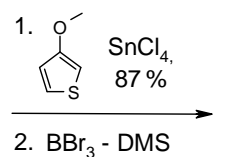

$41 \%$

$\mathrm{HO}$

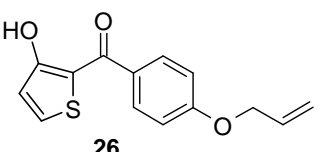

26

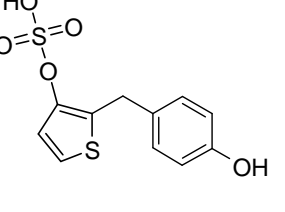

28

Scheme 6. Synthesis of sulfate 28 of AVE2268.

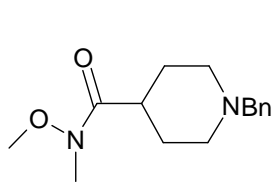

29

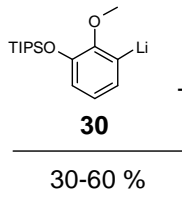

$30-60 \%$<smiles>CCOc1cccc(C(=O)C2CC[NH2+]CC2)c1OC</smiles>

31

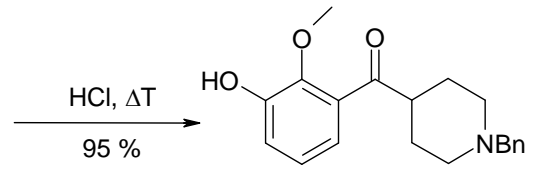

32

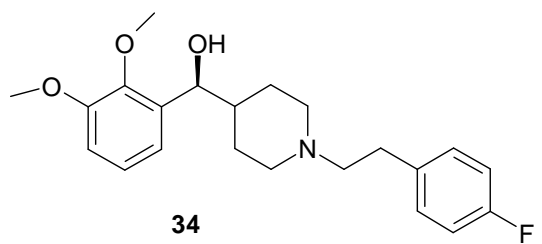

Scheme 7. Synthesis of sulfate of MDL107292 (33).

A further example is shown in scheme 7 wherein sulfate metabolite MDL107292 33 was synthesized in 5 steps with an overall yield of $15 \%{ }^{48} \mathbf{3 3}$ is a metabolite of MDL100907 34, a highly selective 5-HT2A antagonist which is being trialed as a potential antipsychotic, antidepressant or as a treatment for insomnia. ${ }^{49} \mathbf{3 3}$ was prepared starting from Weinreb amide $\mathbf{2 9}$ which was reacted with ortho-lithiated guajacole derivative $\mathbf{3 0}$ to give the resulting ketone $\mathbf{3 1}$ in $30-60 \%$ yield. Yield variations were found to be caused by differing purities of reactants and reagents used. After acidic removal of the TIPS-protecting group the phenol $\mathbf{3 2}$ was reacted with $\mathrm{SO}_{3} \times \mathrm{TEA}$ to form the sulfate in $96 \%$ yield. Finally, after non-enantioselective ketone reduction with sodium borohydride, the benzyl protecting group was removed under Pd-catalyzed hydrogenation transfer conditions to yield the final product $\mathbf{3 3}$ as a racemic mixture. 


\section{General aspects of the analysis of phase II-metabolites}

For analytical synthesis support, in-process control and reliable quality control of phase II metabolites the whole battery of modern small molecule analytics - most importantly HPLC for purity assessment as well as MS and NMR for structural confirmation - is applied.

The one common feature that distinguishes metabolites from their parent molecules is that they are - as a first approximation - more polar.

While this does not usually cause problems for NMR (other than potential solubility issues) or MS (where the higher polarity is rather beneficial in electrospray ionization) it requires, in many cases, changes to the HPLC method.

Many metabolites can be analyzed using the chromatographic method applied to their parent molecule - the very polar ones, though, may require changes to the gradient profile or adjustments of the mobile phase composition, buffer type or $\mathrm{pH}$. The target of such optimizations is to obtain sufficient retention on the stationary phase along with narrow peak shapes, resulting in high peak capacities so that any impurities present can be effectively separated from the analyte.

Even though counter ion chromatography is an inexpensive and suitable way to chromatograph very polar and ionic compounds - it is not applicable for preparative purposes and thus is not a good method for synthesis support. The same is true for ion exchange chromatography. It should be noted at this point that certain modifiers, such as TFA, possess counter ion properties without interfering with the isolation of the target compound.

Two examples from our laboratory which have been discussed above are given below:

\section{Acyl glucuronide of AVE0897 (7)}

An illustration of a typical case is given in Figure 1: the 1- $\beta$ - $O$-acyl glucuronide of AVE0897 (7) is more polar and thus elutes earlier than the parent compound in reverse-phase (RP) mode. The gradient still covers the polarity range so that both compounds can be analyzed and well separated from each other using the same HPLC method.

\section{Sulfate conjugate MDL107292 (33)}

In the case of MDL107292 (33), a sulfate metabolite of MDL100907 34, the gradient method for the parent compound yielded insufficient retention (RP-18 column Waters Symmetry; starting conditions $10 \%$ organic, $0.1 \%$ TFA, not shown). Even a more drastic modification of the conditions to just $1 \%$ organic eluent and an isocratic hold time of 10 min resulted only in a limited increase of retention (Figure 2a). 


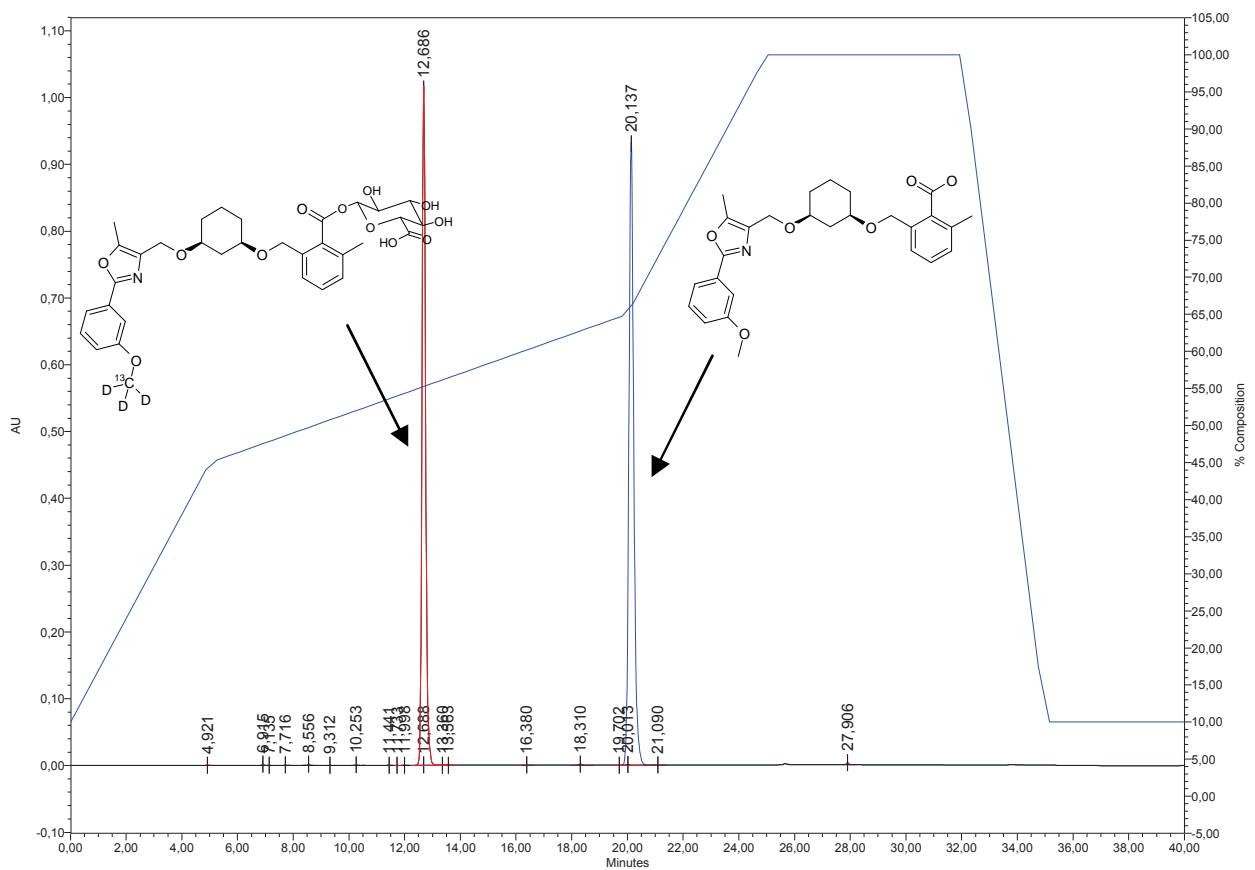

Figure 1. The $O$-acyl glucuronide of AVE0897 (7) is more polar and thus elutes earlier than the parent compound, but the gradient still covers the polarity range so that both compounds can be analyzed and well separated from each other using the same HPLC method.

a)

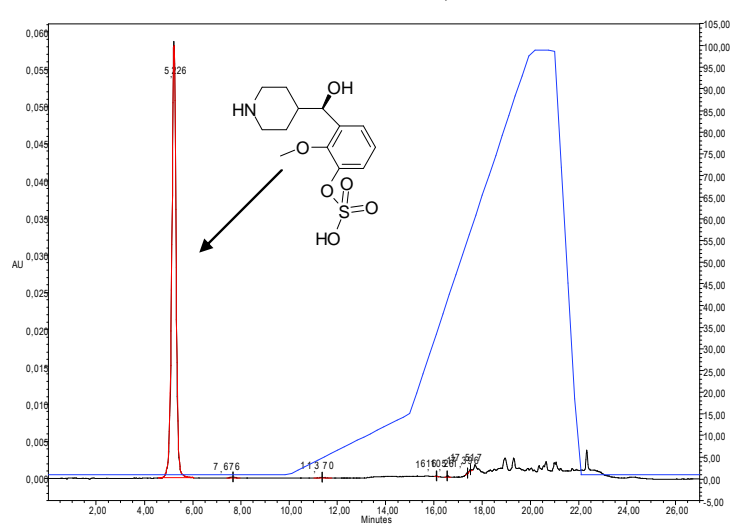

b)

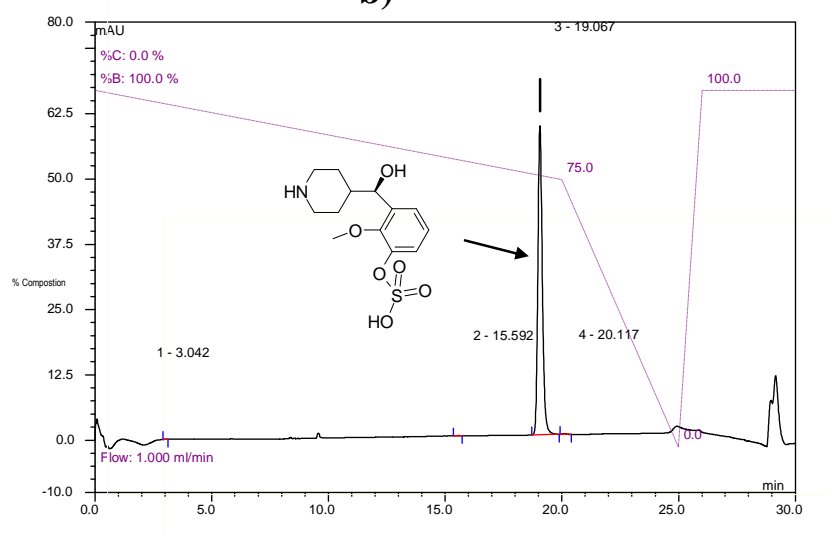

Figure 2. Analysis of MDL107292 (33) using two separation modes: a) while the modified parent RP18 method yielded only very limited retention, b) a HILIC method provided full chromatographic control (peak elutes in a linear section of the HPLC gradient).

As the reversed-phase C-18 ligands of the stationary phase are prone to collapse in such highly aqueous conditions, an "AQ"-type of reversed-phase stationary phase, which can be operated even in $100 \%$ aqueous eluents was also tried as an alternative, but with very similar results (not shown). 
Even though limited retention could be achieved using the two chromatographic systems described above for initial analytical support of the synthesis, the fact that RP-chromatography had been taken to its limits with no room for further variation left (i.e. an almost totally aqueous eluent already in isocratic conditions) made a new method with better retention control necessary. Instead of further types of RP-material, an orthogonal separation mechanism was chosen: Hydrophilic Interaction Chromatography, HILIC. ${ }^{50}$ Here, a partition of the analytes between a less polar mobile phase (typically acetonitrile) and a more polar, aqueous solvation sphere around the stationary phase takes place. Polar analytes are eluted with increasing amounts of aqueous eluent. The elution order is inversed compared to reversed-phase chromatography. Apolar compounds elute prior to polar ones. It has been demonstrated that HILIC shows very high orthogonality to the RP separation mechanism. ${ }^{51}$

The results of such a HILIC chromatogram are shown in Figure 2 (b). The phase II metabolite MDL107292 33 elutes with a linear gradient of increasing levels of aqueous eluent after $19 \mathrm{~min}$ at an aqueous eluent level of approx. $25 \%$. Full chromatographic control is obtained: The gradient profile can be adjusted in order to vary retention times or in case a potential impurity needs to be separated from the main peak.

Under the conditions of HILIC method (6.5 mM ammonium acetate buffer) the analyte MDL 107292 is fully ionized. This is usually beneficial for good HILIC retention, the HILIC interaction taking place between approx. $2.5 \%$ and $30 \%{ }^{52}$ aqueous content. It should be noted that other types of separation mechanisms may contribute to the separation as well, most notably ionic exchange interactions.

\section{Conclusions}

Difficulties associated with the preparation of specific phase II drug metabolites can be varied and challenging. However, to ensure patient safety, the potential toxicological implications of phase II metabolites have to be evaluated, as requested by the FDA, and thus these synthetic challenges need to be overcome. We have summarized methods for the preparation of phase II metabolites which have proved to be successful in our laboratory for the synthesis of selected $O$ glucuronides and sulfates of recent drug development candidates. The $O$-acyl-glucuronide 7 of AVE0897 1 was prepared under Königs-Knorr conditions followed by basic deacylation and enzymatic saponification. $O$-Glucuronide 12 of AVE2268 8 was synthesized by a two step oxidation strategy. The synthesis of SAR7226 $O$-glucuronide 21 encompassed 8 linear steps and used a divergent protecting group strategy. In the synthesis of sulfate $\mathbf{2 8}$ a $\mathrm{NaBH}_{4}$-activated palladium-catalyzed reductive deallylation process was developed in order to overcome catalyst deactivation resulting from traces of sulfur impurities. Sulfate MDL107292 33, a metabolite of MDL100907, was synthesized in 9 steps, demonstrating the possibility for applying a reductive debenzylation as final deprotection step. Analytical release of phase II metabolites proved to be highly challenging due to the typical very polar nature of these compounds. Different analytical 
approaches were discussed based on the examples 1- $\beta$ - $O$-acyl glucuronide of AVE 08977 and sulfate MDL107292 33.

\section{Experimental Section}

General. ${ }^{1} \mathrm{H}(300,500 \mathrm{MHz})$ and ${ }^{13} \mathrm{C}(75,125 \mathrm{MHz}) \mathrm{NMR}$ spectra were obtained on Bruker spectrometers in the solvents indicated. All experiments were carried out under argon in dried glassware, using syringe-septum cap techniques. Column chromatography was carried out using Merck Kieselgel 60 silica gel (particle size: 63-200 $\mu \mathrm{m}$ ). The purity of the products was determined by a LC-MS system with a symmetry Shield RP18 column, 3,9 x 150 mm with gradient program; conditions: mobile phase: A: water $(900 \mathrm{~mL})$, acetonitrile $(100 \mathrm{~mL})$, TFA $(1$ $\mathrm{mL})$ mobile phase $\mathrm{B}$ : water $(100 \mathrm{~mL})$, acetonitrile $(900 \mathrm{~mL})$, TFA $(0.75 \mathrm{~mL})$, flow $1,5 \mathrm{~mL} / \mathrm{min}$, detection UV at $254 \mathrm{~nm}$ and $210 \mathrm{~nm}$. Commercially available chemicals and solvents were used as obtained.

HRMS spectra were recorded on a Bruker $\mu$ OTOF-QII instrument equipped with an ESI source. The sample was introduced in $0.1 \%$ formic acid / acetonitrile or water / acetonitrile using a syringe pump at 3-4 $\mu \mathrm{L} / \mathrm{min}$. Standard resolution MS spectra were recorded on a Bruker Esquire 3000 ion trap instrument at identical conditions.

Analytical HPLC was performed either on a Waters Alliance 2695 or a Dionex Summit instrument equipped with variable wavelength UV- or DAD-detectors using the conditions given at the individual compound sections below.

[Methoxy- $\left.{ }^{13} \mathrm{C}^{2} \mathrm{H}_{3}\right]-$ methyl $\quad$ 1-O-[2-[(1R,3S)-3-[2-(3-methoxyphenyl)-5-methyloxazol-4-ylmethoxy]-cyclohexyloxymethyl]-6-methylbenzoic acid]-2,3,4-tri- $O$-acetyl- $\beta$-D-glucopyranuronate (5). In a flask filled with argon, [methoxy- ${ }^{13} \mathbf{C}^{2} \mathbf{H}_{3}$ ]-AVE0897 (1) (469 mg, $1.00 \mathrm{mmol}$ ) was dissolved in DMSO (8 mL). Cesium carbonate $(326 \mathrm{mg}, 1.00 \mathrm{mmol})$ and acetobromo- $\alpha-\mathrm{D}$ glucuronic acid methyl ester $(532 \mathrm{mg}, 1.34 \mathrm{mmol})$ were added with stirring. The reaction mixture was stirred for $3.5 \mathrm{~h}$ at $30{ }^{\circ} \mathrm{C}$. After complete conversion (LC-MS and TLC, ethyl acetate/heptane 3:2) water $(8 \mathrm{~mL})$ was added and the mixture extracted three times with ethyl acetate $(15 \mathrm{~mL})$. The combined organic layers were washed with water $(20 \mathrm{~mL})$, sodium bicarbonate solution $(8 \mathrm{wt} \%$ in water, $20 \mathrm{~mL})$ and brine $(20 \mathrm{~mL})$. The organic phase was dried over $\mathrm{Na}_{2} \mathrm{SO}_{4}$ and evaporated in vacuo to obtain [methoxy- ${ }^{\mathbf{1 3}} \mathbf{C}^{\mathbf{2}} \mathbf{H}_{\mathbf{3}}$ ]-5 (729 mg, $0.93 \mathrm{mmol}, 93 \%$ yield) as a colorless oil; ${ }^{1} \mathrm{H}-\mathrm{NMR}\left(300 \mathrm{MHz}, \mathrm{ACN}-d_{3}-\mathrm{D}_{2} \mathrm{O} 3: 1\right): \delta=0.96-1.08(\mathrm{~m}, 4 \mathrm{H}), 1.64$ (m, br, 1H), $1.86(\mathrm{~m} \mathrm{br}, 2 \mathrm{H}), 1.96-2.0(\mathrm{~m}, 9 \mathrm{H}), 2.22(\mathrm{~s}, 3 \mathrm{H}), 2.32(\mathrm{~s}, 3 \mathrm{H}), 2.37(\mathrm{~m}, 1 \mathrm{H}), 3.17-$ $3.34(\mathrm{~m}, 2 \mathrm{H}), 3.63(\mathrm{~s}, 3 \mathrm{H}), 4.38(\mathrm{~m}, 2 \mathrm{H}), 4.48(\mathrm{~s}, 2 \mathrm{H}), 5.08-5.19(\mathrm{~m}, 2 \mathrm{H}), 5.42(\mathrm{t}, J=9.4 \mathrm{~Hz}$, $1 \mathrm{H}), 6.11(\mathrm{~d}, J=8.1 \mathrm{~Hz}, 1 \mathrm{H}), 7.0(\mathrm{dd}, J=9.0, J=2.5 \mathrm{~Hz}, 1 \mathrm{H}), 7.19(\mathrm{~m}, 2 \mathrm{H}), 7.32$ (t, $J=7.6 \mathrm{~Hz}$, 1H) $7.38\left(\mathrm{t}, J=8.1 \mathrm{~Hz}, 7.46(\mathrm{~s}, 1 \mathrm{H}), 7.50(\mathrm{t}, J=7.7 \mathrm{~Hz}, 1 \mathrm{H}) \mathrm{ppm} ;{ }^{13} \mathrm{C}-\mathrm{NMR}\left(75 \mathrm{MHz}, \mathrm{ACN}-\mathrm{d}_{3}\right.\right.$ - $\left.\mathrm{D}_{2} \mathrm{O} 3: 1\right): \delta=10.42,14.42,19.70,20.75,20.85,20.99,21.28,32.20,32.24,39.02,53.78,55.40$ (sept. $J=21.7 \mathrm{~Hz}, \mathrm{O}^{13} \mathrm{CD}_{3}$ ), 61.76, 68.36, 69.97, 70.90, 72.51, 73.18, 76.56, 76.95, 92.64, 
101.00, $111.75(\mathrm{~d}, J=4.5 \mathrm{~Hz}), 117.35(\mathrm{~d}, J=4.5 \mathrm{~Hz}), 119.25,127.29,129.40,130.95,131.31$, 131.41, 131.80, 134.06, 136.66, 137.70, 148.38, 169.32, 160.87, 168.14, 168.33, 170.97, 171.40, 171.59 ppm; MS $\left(\mathrm{ESI}^{+}\right) \mathrm{m} / z(\%): 786.3\left[\mathrm{M}+\mathrm{H}^{+}\right](100), 808.3\left[\mathrm{M}+\mathrm{Na}^{+}\right](60) ; \mathrm{HRMS}\left(\mathrm{ESI}^{+}\right): \mathrm{m} / z$ $=808.3067$ [calc. for $\mathrm{C}_{39}{ }^{13} \mathrm{CH}_{44}{ }^{2} \mathrm{H}_{3} \mathrm{NO}_{15}+\mathrm{Na}: 808.3059$ ].

[Methoxy- $\left.{ }^{13} \mathrm{C}^{2} \mathrm{H}_{3}\right]$-methyl 1-O-[2-[(1R,3S)-3-[2-(3-methoxyphenyl)-5-methyloxazol4-yl-methoxy]-cyclohexyloxymethyl]-6-methylbenzoic acid]- $\beta$-D-glucopyranuronate (6). In a flask filled with argon, [methoxy- ${ }^{\mathbf{1 3}} \mathbf{C}^{\mathbf{2}} \mathbf{H}_{3}$ ]-5 $(726 \mathrm{mg}, 0.93 \mathrm{mmol})$ was dissolved in dry methanol (8 mL). $220 \mu \mathrm{L} \mathrm{N}, \mathrm{N}$-diisopropylethylamine $(1.1 \mathrm{mmol}, 1.72$ eq.) was added and the reaction mixture stirred for $72 \mathrm{~h}$ at room temperature. After complete conversion (LC-MS and TLC, dichloromethane/methanol/glacial acetic acid 950:50:1), the solvent was removed in vacuo and the residue purified by column chromatography on silica gel eluting with dichloromethane/methanol/glacial acetic acid 950:50:1. Selected fractions containing the product were pooled and concentrated in vacuo to obtain [methoxy- ${ }^{13} \mathbf{C}^{\mathbf{2}} \mathbf{H}_{\mathbf{3}}$ ]-6 (549 $\mathrm{mg}, 0.83 \mathrm{mmol}, 89$ $\%$ yield) as a colorless solid; ${ }^{1} \mathrm{H}-\mathrm{NMR}\left(300 \mathrm{MHz}, \mathrm{ACN}-d_{3}-\mathrm{D}_{2} \mathrm{O} 3: 1\right): \delta=0.9-1.1(\mathrm{~m}, 4 \mathrm{H}), 1.65$ (m, br, 1H), 1.78-1.96 (m, 2H), $2.24(\mathrm{~s}, 3 \mathrm{H}), 2.28(\mathrm{~s}, 3 \mathrm{H}), 2.32(\mathrm{~m}, 1 \mathrm{H}), 3.18-3.28(\mathrm{~m}, 2 \mathrm{H}), 3.50-$ $3.57(\mathrm{~m}, 3 \mathrm{H}), 3.69(\mathrm{~s}, 3 \mathrm{H}), 4.03-4.09(\mathrm{~m}, 1 \mathrm{H}), 4.36(\mathrm{~s}, 2 \mathrm{H}), 4.52(\mathrm{q}, J=8.3 \mathrm{~Hz}, 2 \mathrm{H}), 5.74(\mathrm{~d}, J=$ $7.98 \mathrm{~Hz}, 1 \mathrm{H}), 6.98(\mathrm{dd}, J=8.2 \mathrm{~Hz}, J=1.98 \mathrm{~Hz}, 1 \mathrm{H}), 7.13-7.20(\mathrm{~m}, 2 \mathrm{H}), 7.24-7.30(\mathrm{~m}, 1 \mathrm{H}), 7.37$ $(\mathrm{t}, J=8.07 \mathrm{~Hz}, 1 \mathrm{H}), 7.42(\mathrm{~m}, 1 \mathrm{H}), 7.46(\mathrm{~d}, 7.74,1 \mathrm{H}) \mathrm{ppm} ;{ }^{13} \mathrm{C}-\mathrm{NMR}\left(75 \mathrm{MHz}, \mathrm{ACN}-\mathrm{d}_{3}-\mathrm{D}_{2} \mathrm{O}\right.$ 3:1): $\delta=10.37,19.73,21.11,31.93,32.02,36.66,53.58,55.43$ (sept. $J=21.75 \mathrm{~Hz}, \mathrm{O}^{13} \mathrm{CD}_{3}$ ), $61.49,68.45,72.04,72.86,76.19,76.41,76.51,76.93,95.41,111.77(\mathrm{~d}, J=4.5 \mathrm{~Hz}), 117.42(\mathrm{~d}, J$ $=4.5 \mathrm{~Hz}), 127.35,129.03,131.04,131.21,131.34,132.35,133.58,136.93,137.01,148.63$, 160.40, 160.66, 169.02, 170.54 ppm; MS (ESI $\left.{ }^{+}\right) \mathrm{m} / z(\%): 660.3\left[\mathrm{M}+\mathrm{H}^{+}\right](100), 682.3\left[\mathrm{M}+\mathrm{Na}^{+}\right]$ (50); HRMS (ESI $\left.{ }^{+}\right): m / z=660.2939$ [calc. for $\mathrm{C}_{33}{ }^{13} \mathrm{CH}_{38}{ }^{2} \mathrm{H}_{3} \mathrm{NO}_{12}+\mathrm{H}: 660.2923$ ].

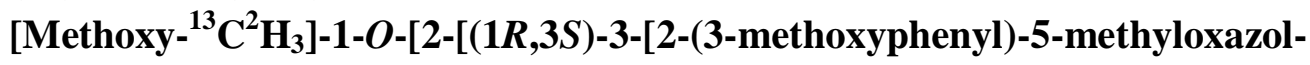

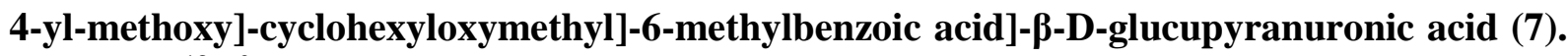
[methoxy- ${ }^{13} \mathbf{C}^{\mathbf{2}} \mathbf{H}_{3}$ ]-6 (549 $\mathrm{mg}, 0.83 \mathrm{mmol}$ ) was dissolved in isopropanol (4 mL), $2.5 \mathrm{mM} \mathrm{pH} 7$ phosphate buffer $(24 \mathrm{~mL})$ and subsequently Candida antarctica lipase (CAL-B) $(820 \mathrm{mg}$ ) were added. The reaction mixture was stirred for $36 \mathrm{~h}$ at room temperature. After complete conversion (LC-MS and TLC, dichloromethane/methanol/glacial acetic acid 950:50:1), isopropanol was removed in vacuo. Water $(10 \mathrm{~mL})$ was added and the mixture was extracted with ethyl acetate $(3 \times 10 \mathrm{~mL})$. The combined organic layers were washed with water $(10 \mathrm{~mL})$ and brine $(10 \mathrm{~mL})$. The organic phase was dried over $\mathrm{Na}_{2} \mathrm{SO}_{4}$ and evaporated in vacuo to obtain crude [methoxy${ }^{13} \mathbf{C}^{\mathbf{2}} \mathbf{H}_{3}$ ]-7 (491 mg, (0.76 mmol, 91\% yield) as a colorless solid with a purity of 94\% (LC-MS). The crude product was further purified by preparative HPLC (column Phenomenex Gemini C18, 250 × $50 \mathrm{~mm} ; 10 \mu \mathrm{m}$ particle size; flow rate: $100 \mathrm{ml} / \mathrm{min}$; eluent A: TFA $0.05 \%$, eluent B acetonitrile, gradient program). Fractions containing the product (LC-MS) were pooled and neutralized by addition of bicarbonate solution. The product was precipitated by evaporation of the organic solvent, filtered off and dried over $\mathrm{CaCl}_{2}$ in vacuo to afford [methoxy- ${ }^{13} \mathbf{C}^{\mathbf{2}} \mathbf{H}_{3}$ ] $-\mathbf{7}$ (239 mg, $0.37 \mathrm{mmol}, 45 \%$ yield) as a colorless amorphous solid with a purity of $99.8 \%$, (analytical HPLC conditions: HPLC-column: Uptisphere, 150x 4.6mm, $5 \mu \mathrm{m}$ particle size. eluent 
A: water/acetonitrile/TFA 900:100:1 (v/v/v). eluent B: water/acetonitrile/TFA 100:900:0.75 (v/v/v); flow rate: $1 \mathrm{ml} /$ minute; UV detection wavelength: $276 \mathrm{~nm}$; injection volume: $10 \mu 1$. sample solvent: acetonitrile; column temperature: $30{ }^{\circ} \mathrm{C}$; sampler temperature: $15{ }^{\circ} \mathrm{C}$; gradient profile: $0 \mathrm{~min} / 10 \%$ eluent B, $5 \mathrm{~min} / 45 \%$ eluent B, $20 \mathrm{~min} / 65 \%$ eluent B, $25 \mathrm{~min} / 100 \%$ eluent B, $32 \mathrm{~min} / 100 \%$ eluent B, $35 \mathrm{~min} / 10 \%$ eluent B, $40 \mathrm{~min} / 10 \%$ eluent B); ${ }^{1} \mathrm{H}-\mathrm{NMR}(300 \mathrm{MHz}$, $\left.\mathrm{ACN}-d_{3}-\mathrm{D}_{2} \mathrm{O} 3: 1\right): \delta=0.96-1.14(\mathrm{~m}, 4 \mathrm{H}), 1.68(\mathrm{~m}, 1 \mathrm{H}), 1.88(\mathrm{~m}, 1 \mathrm{H}), 1.94(\mathrm{~m}, J=2.4 \mathrm{~Hz}$, $1 \mathrm{H}), 2.29(\mathrm{~s}, 3 \mathrm{H}), 2.33(\mathrm{~s}, 3 \mathrm{H}), 2.37(\mathrm{~m}, 1 \mathrm{H}), 3.28(\mathrm{~m}, 2 \mathrm{H}), 3.40-3.60(\mathrm{~m}, 3 \mathrm{H}), 3.98(\mathrm{~m}, 1 \mathrm{H})$, $4.40(\mathrm{~s}, 2 \mathrm{H}), 4.56(\mathrm{q}, J=13.2 \mathrm{~Hz}, 2 \mathrm{H}), 5.76(\mathrm{~d}, J=7.9 \mathrm{~Hz}, 1 \mathrm{H}), 7.02(\mathrm{dd}, J=8.2 \mathrm{~Hz}, J=2.4$ $\mathrm{Hz}, 1 \mathrm{H}), 7.20(\mathrm{~m} 2 \mathrm{H}), 7.32(\mathrm{t}, J=7.6 \mathrm{~Hz}, 1 \mathrm{H}), 7.39(\mathrm{t}, J=8.9 \mathrm{~Hz}, 1 \mathrm{H}, 7.46(\mathrm{~s}, 1 \mathrm{H}), 7.50(\mathrm{t}, J=$ $7.7 \mathrm{~Hz}, 1 \mathrm{H}) \mathrm{ppm} ;{ }^{13} \mathrm{C}-\mathrm{NMR}\left(75 \mathrm{MHz}, \mathrm{ACN}-d_{3}-\mathrm{D}_{2} \mathrm{O} 3: 1\right): \delta=10.40,19.82,21.19,32.09$, 32.15, 39.03, 55.45 (sept, $J=21.7 \mathrm{~Hz}, \mathrm{O}^{13} \mathrm{CD}_{3}$ ), 61.64, 68.57, 72.13, 72.99, 76.48, 76.77, 77.17, 95.53, 111.80 (d, $J=4.5 \mathrm{~Hz}), 117.53$ (d, $J=4.5 \mathrm{~Hz}), 119.35,127.42,129.27,131.03,131.17$, $131.37,132.63,133.82,137.00,137.32,148.54,160.48,160.84,169.01 \mathrm{ppm} ; \mathrm{MS}\left(\mathrm{ESI}^{+}\right) \mathrm{m} / z$ (\%): $646.3\left[\mathrm{M}+\mathrm{H}^{+}\right](100)$; $\mathrm{MS}\left(\mathrm{ESI}^{-}\right) \mathrm{m} / \mathrm{z}(\%): 644.2\left[\mathrm{M}-\mathrm{H}^{+}\right](100) ; \mathrm{HRMS}\left(\mathrm{ESI}^{+}\right): \mathrm{m} / z=$ 646.2773 [calc. for $\mathrm{C}_{32}{ }^{13} \mathrm{CH}_{36}{ }^{2} \mathrm{H}_{3} \mathrm{NO}_{12}+\mathrm{H}$ : 646.2767].

2-Benzyl-4-(4-methoxybenzyl)-5-trifluoromethyl-2H-pyrazol-3-(4-desoxy-4-fluoro-6- $O$-tertbutyl-dimethylsilyl)- $\beta$-D-glucopyranosid (17). Tri- $O$-benzoyl-protected compound 16, (7.2 g, $8.6 \mathrm{mmol}) \mathrm{MeOH}(150 \mathrm{~mL})$ and $30 \% \mathrm{NaOMe}$ in $\mathrm{MeOH}(1.5 \mathrm{~mL})$ were stirred at $20-23{ }^{\circ} \mathrm{C}$ for 2 h. During the reaction the white suspension turned to a clear colorless solution. After complete conversion (tlc, ethyl acetate/heptane 2:1) saturated aqueous $\mathrm{NH}_{4} \mathrm{Cl}$ solution $(50 \mathrm{~mL}$ ) was added; the resultant mixture was filtered and evaporated in vacuo. Addition of water and threefold extraction with ethyl acetate, drying of the combined organic phases with $\mathrm{Na}_{2} \mathrm{SO}_{4}$ and evaporation to dryness yielded $7.3 \mathrm{~g}$ of crude $N$-benzyl-protected SAR7226 (along with benzoic acid methyl ester). For regioselective silylation, this material was dissolved in dichloromethane $(75 \mathrm{~mL})$. Then triethylamine $(2.4 \mathrm{~mL}, 17.1 \mathrm{mmol})$ and a catalytic amount of 4-dimethylaminopyridine (DMAP) were added. The mixture was stirred at at $20-23{ }^{\circ} \mathrm{C}$ and a solution of TBDMS chloride $(2.5 \mathrm{~g}, 16.5 \mathrm{mmol})$ in dichloromethane $(4 \mathrm{~mL})$ was added. After $30 \mathrm{~h}$ the conversion of the starting material was almost complete. Water $(25 \mathrm{~mL})$ was added and the $\mathrm{pH}$ was adjusted to 3-4 with saturated aqueous $\mathrm{KHSO}_{4}$. The phases were separated; the organic phase was washed with brine and water. Drying of the combined organic phases with $\mathrm{Na}_{2} \mathrm{SO}_{4}$ and evaporation in vacuo gave $9 \mathrm{~g}$ of crude 17. Chromatography on silica gel (n-heptane/ethyl acetate 1:0 $\rightarrow$ 1:2) followed by evaporation gave 17 (4.65 g, $7.3 \mathrm{mmol}, 84 \%$ yield) as a sticky, almost colorless foam; ${ }^{1} \mathrm{H}$ NMR (500 MHz, $\left.\mathrm{CDCl}_{3}\right): \delta=0.05$ (s, 6H), 0.89 (s, 9H), 2.52 (br, 1H), 2.73 (br, 1H), $3.11(\mathrm{~m}, 1 \mathrm{H}), 3.53(\mathrm{t}, J=8.6 \mathrm{~Hz}, 1 \mathrm{H}), 3.62(\mathrm{dt}, J=15.1,9.1 \mathrm{~Hz}, 1 \mathrm{H}), 3.73(\mathrm{~s}, 2 \mathrm{H}), 3.78(\mathrm{~s}, 3 \mathrm{H})$, $3.90(\mathrm{~m}, 2 \mathrm{H}), 4.43(\mathrm{dt}, J=50.5,9.1 \mathrm{~Hz}, 1 \mathrm{H}), 4.50(\mathrm{~d}, J=7.7 \mathrm{~Hz}, 1 \mathrm{H}), 5.30(\mathrm{~d}, J=15.3 \mathrm{~Hz}, 1 \mathrm{H})$, $5.41(\mathrm{~d}, J=15.3 \mathrm{~Hz}, 1 \mathrm{H}), 6.81(\mathrm{~d}, J=8.7 \mathrm{~Hz}, 2 \mathrm{H}), 7.05(\mathrm{~d}, J=8.7 \mathrm{~Hz}, 2 \mathrm{H}), 7.22(\mathrm{~d}, J=6.9 \mathrm{~Hz}$, 2H), 7.28-7.36 (m, 3H) ppm; MS (ESI'): $m / z(\%)=360.9$ (31), 685.1 (100) [M+HCOO']; HRMS $\left(\mathrm{ESI}^{+}\right): m / z=663.2479$ [calc. for $\mathrm{C}_{31} \mathrm{H}_{40} \mathrm{~F}_{4} \mathrm{~N}_{2} \mathrm{O}_{6} \mathrm{Si}+\mathrm{Na}: 663.2489$ ].

2-Benzyl-4-(4-methoxybenzyl)-5-trifluoromethyl-2H-pyrazol-3-(2,3-di-O-benzyl-4-desoxy-

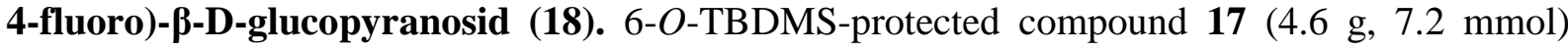


was dissolved in THF (5 mL), and $\mathrm{NaH}(1.70 \mathrm{~g}, 42.5 \mathrm{mmol})$ was added and the mixture stirred for $45 \mathrm{~min}$ at $20-23{ }^{\circ} \mathrm{C}$. To the resulting white suspension, benzyl bromide (3.5 mL, $29.4 \mathrm{mmol}$ ) was added over a period of $10 \mathrm{~min}$. After stirring for $4 \mathrm{~h}$ saturated aqueous $\mathrm{NH}_{4} \mathrm{Cl}$ was added, the phases were separated, the aqueous phase was extracted several times with ethyl acetate and the combined organic phases were dried $\left(\mathrm{Na}_{2} \mathrm{SO}_{4}\right)$ and evaporated in vacuo. The crude 6-OTBDMS-2,3-O-benzyl-protected compound $(9.5 \mathrm{~g}, \leq 7.1 \mathrm{mmol})$ was used for the next step without further purification and characterization. For desilylation this material was dissolved in THF $(100 \mathrm{~mL})$ and treated with $\mathrm{Bu}_{4} \mathrm{NF}(2.4 \mathrm{~g}, 7.6 \mathrm{mmol})$ with stirring at 20-23 ${ }^{\circ} \mathrm{C}$. After $90 \mathrm{~min}$ saturated aqueous $\mathrm{NH}_{4} \mathrm{Cl}$ solution was added, the phases were separated, the organic phase was washed with water, dried $\left(\mathrm{Na}_{2} \mathrm{SO}_{4}\right)$, evaporated in vacuo and purified by chromatography on silica gel (ethyl acetate/n-heptane 1:3 $\rightarrow$ 1:0) yielding $18(4.2 \mathrm{~g}, 5.8 \mathrm{mmol}, 80 \%)$ as a colorless foam; ${ }^{1} \mathrm{H}$ NMR $\left(500 \mathrm{MHz}, \mathrm{CDCl}_{3}\right): \delta=2.89(\mathrm{~m}, 1 \mathrm{H}), 3.47(\mathrm{~s}, 2 \mathrm{H}), 3.51(\mathrm{t}, J=8.3 \mathrm{~Hz}, 1 \mathrm{H}), 3.56$ $(\mathrm{dt}, J=15.3,8.9 \mathrm{~Hz}, 1 \mathrm{H}), 3.76(\mathrm{~s}, 3 \mathrm{H}), 3.82(\mathrm{~d}, J=16.6 \mathrm{~Hz}, 1 \mathrm{H}), 3.94(\mathrm{~d}, J=16.6 \mathrm{~Hz}, 1 \mathrm{H})$, $4.46(\mathrm{dt}, J=50.2,9.1 \mathrm{~Hz}, 1 \mathrm{H}), 4.68(\mathrm{~d}, J=7.5 \mathrm{~Hz}, 1 \mathrm{H}), 4.71-4.85(\mathrm{~m}, 4 \mathrm{H}), 5.27$ (d, $J=15.6$ $\mathrm{Hz}, 1 \mathrm{H}), 5.30(\mathrm{~d}, J=15.6 \mathrm{~Hz}, 1 \mathrm{H}), 6.79(\mathrm{~d}, J=8.7 \mathrm{~Hz}, 2 \mathrm{H}), 7.01(\mathrm{~d}, J=8.7 \mathrm{~Hz}, 2 \mathrm{H}), 7.16-7.23$ $(\mathrm{m}, 4 \mathrm{H}), 7.26-7.39(\mathrm{~m}, 11 \mathrm{H}) \mathrm{ppm}$; MS $\left(\mathrm{ESI}^{-}\right): \mathrm{m} / z(\%)=360.9(11), 571.0$ (29), 751.2 (100) [M+HCOO']; HRMS (ESI $\left.{ }^{+}\right): m / z=729.2544$ [calc. for $\mathrm{C}_{39} \mathrm{H}_{38} \mathrm{~F}_{4} \mathrm{~N}_{2} \mathrm{O}_{6}+\mathrm{Na}: 729.2558$ ]

\section{2-Benzyl-4-(4-methoxybenzyl)-5-trifluoromethyl-2H-pyrazol-3-(2,3-di-O-benzyl-4-desoxy-} 4-fluoro)- $\beta$-D-glucopyranosyl-(2,3,4-tri- $O$-pivaloyl)- $\beta$-D-glucopyranosiduronic acid (20). The 6-OH-deprotected compound 18 (740 mg, $1.1 \mathrm{mmol})$ dissolved in dichloromethane $(5 \mathrm{~mL})$ was added under argon to a solution of glucuronyl donor 19 (890 $\mathrm{mg}, 1.6 \mathrm{mmol})$ in dichloromethane $(5 \mathrm{~mL})$ over $4 \AA$ molecular sieves. After stirring for $30 \mathrm{~min}$ at $20-23{ }^{\circ} \mathrm{C}$ the slightly yellow solution was cooled to $-12{ }^{\circ} \mathrm{C}$ (ice/ethanol) and AgOTf (400 mg, $1.5 \mathrm{mmol}$ ) added. The reaction mixture was stirred for $5 \mathrm{~h}$ at -12 to $-10{ }^{\circ} \mathrm{C}$ the color changing from slightly yellow to blue-purple. After filtration and purification of the filtrate by chromatography on silica gel (elution with ethyl acetate/toluene 1:8) the fully protected disaccharide $20(870 \mathrm{mg} ; 0.75$ mmol) was isolated by evaporation as a colorless solid; ${ }^{1} \mathrm{H}$ NMR $\left(500 \mathrm{MHz}, \mathrm{DMSO}-d_{6}\right): \delta=$ $1.05(\mathrm{~s}, 9 \mathrm{H}), 1.07(\mathrm{~s}, 9 \mathrm{H}), 1.10(\mathrm{~s}, 9 \mathrm{H}), 3.54(\mathrm{t}, J=8.3 \mathrm{~Hz}, 1 \mathrm{H}), 3.62(\mathrm{~s}, 3 \mathrm{H}), 3.68(\mathrm{~s}, 3 \mathrm{H}), 3.60-$ $3.93(\mathrm{~m}, 6 \mathrm{H}), 4.43-4.76(\mathrm{~m}, 6 \mathrm{H}), 4.85(\mathrm{~m}, 2 \mathrm{H}), 4.99(\mathrm{t}, J=9.6 \mathrm{~Hz}, 1 \mathrm{H}), 5.13(\mathrm{~d}, J=7.5 \mathrm{~Hz}, 1 \mathrm{H})$, $5.26(\mathrm{~d}, J=15.5 \mathrm{~Hz}, 1 \mathrm{H}), 5.36(\mathrm{~d}, J=15.5 \mathrm{~Hz}, 1 \mathrm{H}), 5.44(\mathrm{~m}, 1 \mathrm{H}), 6.78(\mathrm{~d}, J=8.5 \mathrm{~Hz}, 2 \mathrm{H}), 6.96$ $(\mathrm{d}, J=8.5 \mathrm{~Hz}, 2 \mathrm{H}), 7.05$. (d, $J=7.5 \mathrm{~Hz}, 2 \mathrm{H}), 7.14-7.38(\mathrm{~m}, 13 \mathrm{H}) \mathrm{ppm} ; \mathrm{MS}\left(\mathrm{ESI}^{+}\right): \mathrm{m} / z(\%)=$ 1149.4 (100) $\left[\mathrm{M}+\mathrm{H}^{+}\right]$; HRMS $\left(\mathrm{ESI}^{+}\right): m / z=1149.4942$ [calc. for $\mathrm{C}_{61} \mathrm{H}_{72} \mathrm{~F}_{4} \mathrm{~N}_{2} \mathrm{O}_{15}+\mathrm{H}$ : $1149.4948]$.

\section{4-(4-Methoxybenzyl)-5-trifluoromethyl-2H-pyrazol-3-(4-desoxy-4-fluoro)- $\beta$-D-} glucopyranosyl $\boldsymbol{\beta}$-D-glucopyranosiduronic acid (21). Fully protected disaccharide 20 (460 mg, $0.4 \mathrm{mmol})$ was dissolved in $\mathrm{MeOH}(5 \mathrm{~mL})$, treated with 5-10\% $\mathrm{Pd} / \mathrm{C}$ (140 mg, water content $54 \%$, Degussa), and the reaction mixture was hydrogenated at $35^{\circ} \mathrm{C} / 5$ bar for $15 \mathrm{~h}$. The catalyst was removed by filtration, washed with $\mathrm{MeOH}$ and dichloromethane, and the combined organic solutions were evaporated under reduced pressure. $350 \mathrm{mg}$ of a white foam were isolated. 
Chromatography on silicagel (elution with ethyl acetate/n-heptane 2:1) gave the pure debenzylated product $(290 \mathrm{mg}$ ) as a colorless solid.

$140 \mathrm{mg}$ of this debenzylated ester-protected disaccharide were dissolved in methanol $(15 \mathrm{~mL})$ and water $(15 \mathrm{~mL}) . \mathrm{Ba}(\mathrm{OH})_{2}(200 \mathrm{mg}, 1.2 \mathrm{mmol})$ was added and the reaction mixture was stirred at $20-23{ }^{\circ} \mathrm{C}$ for 2 days. To completely remove the pivaloyl groups, further $\mathrm{Ba}(\mathrm{OH})_{2}(100 \mathrm{mg})$, methanol $(30 \mathrm{~mL})$ and water $(10 \mathrm{~mL})$ were added and the reaction mixture was stirred at $50{ }^{\circ} \mathrm{C}$ for 2 days. After complete saponification, $1 \mathrm{~N} \mathrm{H}_{2} \mathrm{SO}_{4}(1.2 \mathrm{~mL})$ was added $(\mathrm{pH} \sim 5-6)$ and the resulting precipitate filtered off, then washed with water and methanol. Filtrate and washings were combined and evaporated in vacuo yielding crude 21 (160 mg). Chromatography on silica gel (elution with dichloromethane/methanol 9:1 $\rightarrow$ 4:1 $\rightarrow 2: 1$ ) yielded a colorless solid (110 mg) which was further purified by preparative HPLC using a YMC Pro C18 RS column $(5 \mu \mathrm{m}, 150$ $\times 20 \mathrm{~mm}$; flow rate $10 \mathrm{~mL} / \mathrm{min}$; gradient: $15 \mathrm{~min}$, water- $\mathrm{CH}_{3} \mathrm{CN}$ 90:10 $\rightarrow$ 50:50). Two batches of 21 were isolated: $52 \mathrm{mg}$ with a purity of $98.6 \%$ and $44 \mathrm{mg}$ with $93.2 \%$ purity; ${ }^{1} \mathrm{H}$ NMR (500 $\mathrm{MHz}, \mathrm{CD}_{3} \mathrm{CN}: \mathrm{D}_{2} \mathrm{O} 1: 1+0.1 \%$ DCOOD) $\delta=3.21(\mathrm{dd}, J=9.2,8.0 \mathrm{~Hz}, 1 \mathrm{H}), 3.36(\mathrm{t}, J=9.1 \mathrm{~Hz}$, $1 \mathrm{H}), 3.45(\mathrm{~m}, 2 \mathrm{H}), 3.67(\mathrm{~d}, J=9.8 \mathrm{~Hz}, 1 \mathrm{H}), 3.7-3.8(\mathrm{~m}, 8 \mathrm{H}), 4.02(\mathrm{~m}, 1 \mathrm{H}), 4.35(\mathrm{~d}, J=7.9 \mathrm{~Hz}$, $1 \mathrm{H}), 4.38(\mathrm{dt}, J=50.5,8.9 \mathrm{~Hz}, 1 \mathrm{H}), 5.04(\mathrm{~d}, J=7.9 \mathrm{~Hz}, 1 \mathrm{H}), 6.82(\mathrm{~d}, J=8.7 \mathrm{~Hz}, 2 \mathrm{H}), 7.10(\mathrm{~d}, J$ $=8.7 \mathrm{~Hz}, 2 \mathrm{H}) \mathrm{ppm} ;{ }^{13} \mathrm{C} \mathrm{NMR}\left(75 \mathrm{MHz}, \mathrm{CD}_{3} \mathrm{CN}: \mathrm{D}_{2} \mathrm{O} 1: 1+0.1 \%\right.$ DCOOD) $\delta=26.41,56.04$, 68.70, 72.67, 73.36, 73.48, 73.63, 73.96, 74.34, 74.58, 76.18, 76.52, 88.15, 90.55, 102.63, $103.87,106.23,114.80,130.15,130.39,133.13,158.65 \mathrm{ppm} ; \mathrm{MS}\left(\mathrm{ESI}^{+}\right): \mathrm{m} / z(\%)=273.0(20)$,

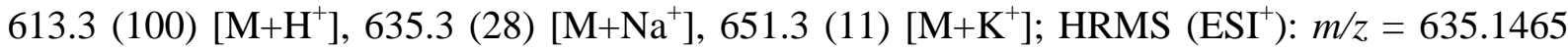
[calc. for $\mathrm{C}_{24} \mathrm{H}_{28} \mathrm{~F}_{4} \mathrm{~N}_{2} \mathrm{O}_{12}+\mathrm{Na}$ : 635.1471].

(1-Benzylpiperidin-4-yl)-(2-methoxy-3-triisopropylsilanyloxyphenyl)methanone (31). The lithiated TIPS-protected guajacole 30 was prepared by adding tert-butyllithium (1.5 $\mathrm{M}$ in pentane, $14.3 \mathrm{~mL}, 21.6 \mathrm{mmol})$ to a solution of TIPS-protected guajacole $(2.00 \mathrm{~g}, 7.14 \mathrm{mmol})$ in diethylether at $0{ }^{\circ} \mathrm{C}$. The solution was stirred for $45 \mathrm{~min}$ at $0{ }^{\circ} \mathrm{C}$ and a solution of Weinreb amide 29 dissolved in diethylether $(10 \mathrm{~mL})$ was added via cannula. The reaction mixture was allowed to warm to room temperature and was quenched with ammonium chloride solution $(25 \mathrm{~mL})$ after 16 hours. The organic phase was washed with brine $(2 \times 25 \mathrm{~mL})$ and dried over magnesium sulfate. Filtration, followed by evaporation of solvent gave the crude product as a yellow oil which was purified by column chromatography on silica gel, eluted with heptane/ethyl acetate 3:1) to give $31(1.1 \mathrm{~g} ; 2.28 \mathrm{mmol}, 32 \%)$ as a colorless oil. ${ }^{1} \mathrm{H}-\mathrm{NMR}\left(300 \mathrm{MHz}, \mathrm{CDCl}_{3}\right): \delta=$ 0.80-0.82 (m, 18H), 1.01-1.07 (m, 6H), 1.23-1.41 (m, 4H), 2.23-2.37 (m, 2H), 2.81-2.88 (m, 2H), $3.48(\mathrm{~s}, 3 \mathrm{H}), 7.16-7.23(\mathrm{~m}, 8 \mathrm{H}) \mathrm{ppm} ;{ }^{13} \mathrm{C}-\mathrm{NMR}\left(75 \mathrm{MHz}, \mathrm{CDCl}_{3}\right): \delta=12.83,17.86,27.80$, 29.12, 29.92, 36.03, 37.23, 52.98, 63.10, 76.57, 120.75, 123.03, 124.08, 127.12, 128.22, 129.17, 129.25, 137.81, 148.75, 149.41, 213.53 ppm; MS (ESI $\left.{ }^{+}\right) \mathrm{m} / z(\%): 482\left[\mathrm{M}+\mathrm{H}^{+}\right](100) ; \mathrm{HRMS}$ $\left(\mathrm{ESI}^{+}\right): m / z=482.3085$ [calc. for $\mathrm{C}_{29} \mathrm{H}_{44} \mathrm{NO}_{3} \mathrm{Si}+\mathrm{H}: 482.3012$ ]

(1-Benzylpiperidin-4-yl)-(2-methoxy-3-hydroxyphenyl)methanone (32). Compound 31 (1.1 $\mathrm{g}, 2.28 \mathrm{mmol})$ was dissolved in ethanol $(4 \mathrm{~mL})$ and conc. $\mathrm{HCl}(2 \mathrm{~mL})$ was added at room temperature. The mixture was heated to $90{ }^{\circ} \mathrm{C}$ for $2 \mathrm{~h}$ and then evaporated to dryness in vacuo. The residue was dissolved in ethanol and again evaporated to dryness in vacuo. The residue was 
washed with n-heptane $(20 \mathrm{~mL})$ and adjusted to $\mathrm{pH} 5$ with $2 \mathrm{~N} \mathrm{NaOH}$. The product was extracted with dichloromethane $(3 \times 30 \mathrm{~mL})$, and the combined organic phases were dried over $\mathrm{Na}_{2} \mathrm{SO}_{4}$ and the solvent was evaporated in vacuo to give 32 (704 mg, $2.17 \mathrm{mmol}, 95 \%)$ as a colorless solid. ${ }^{1} \mathrm{H}-\mathrm{NMR}\left(300 \mathrm{MHz}, \mathrm{CDCl}_{3}\right.$ ): $\delta=0.78-0.0 .97(\mathrm{~m}, 2 \mathrm{H}), 1.00-1.23(\mathrm{~m}, 2 \mathrm{H}), 1.72-1.87$ (m, $3 \mathrm{H}), 2.12-2.35(\mathrm{~m}, 2 \mathrm{H}), 2.85-2.90(\mathrm{~m}, 2 \mathrm{H}), 3.00-3.09$ (br s, $1 \mathrm{H}, \mathrm{OH}), 3.75$ (s, 3H, OMe), 6.86 $(\mathrm{dd}, J=7.4,2.1 \mathrm{~Hz}, 1 \mathrm{H}), 6.93(\mathrm{dd}, J=8.0,7.4 \mathrm{~Hz}, 1 \mathrm{H}), 6.98(\mathrm{dd}, J=8.0,2.1 \mathrm{~Hz}, 1 \mathrm{H}), 7.21-$ $7.32(\mathrm{~m}, 5 \mathrm{H}) \mathrm{ppm} ;{ }^{13} \mathrm{C}-\mathrm{NMR}\left(75 \mathrm{MHz}, \mathrm{CDCl}_{3}\right): \delta=29.10,51.47,62.61,62.87,77.20,100.00$, $118.82,120.19,124.87,127.79,128.46,129.71,132.47,145.15,149.37,205.17$ ppm; MS $\left(\mathrm{ESI}^{+}\right.$.) $\mathrm{m} / \mathrm{z}(\%): 326\left[\mathrm{M}+\mathrm{H}^{+}\right](100)$; HRMS $\left(\mathrm{ESI}^{+}\right): \mathrm{m} / z=326.1751$ [calc. for $\mathrm{C}_{20} \mathrm{H}_{24} \mathrm{NO}_{3}+\mathrm{H}$ : 326.1678].

Sulfuric acid mono-[2-methoxy-3-(1-piperidin-4-yl-ethyl)phenyl]ester (33). Phenol 32 (913 $\mathrm{mg}, 2.80 \mathrm{mmol})$ was dissolved in dichloromethane $(15 \mathrm{~mL})$ and triethylamine $(7.6 \mathrm{~mL})$. At room temperature, sulfurtrioxide triethylamine complex $(2.56 \mathrm{~g}, 14.0 \mathrm{mmol})$ was added in portions as a solid. The reaction mixture was stirred at room temperature for two days and the progress of the reaction was followed by LC-MS. Then the solvent was evaporated in vacuo and the residue was purified by chromatography on silica gel, eluted with dichloromethane/methanol $(5: 1)$ to give) the sulfate $(1.09 \mathrm{~g}, 2.69 \mathrm{mmol})$ as an orange oil. This material was used without further purification in the next reaction step.

The above sulfate $(1.09 \mathrm{~g}, 2.69 \mathrm{mmol})$ was dissolved in methanol $(10 \mathrm{~mL})$ and sodium borohydride (1.07 g, $26.9 \mathrm{mmol})$ was added in portions. The mixture was stirred for $16 \mathrm{~h}$ at room temperature (LC-MS control). After complete conversion, water $(10 \mathrm{~mL})$ was added and the mixture was extracted three times with dichloromethane/n-butanol $(5: 1,3$ x $40 \mathrm{~mL})$. The combined organic phases were dried over $\mathrm{Na}_{2} \mathrm{SO}_{4}$ and the solvent removed in vacuo to give the crude product as a colorless oil which was directly used in the next reaction step.

Under argon atmosphere $\mathrm{Pd} / \mathrm{C}(5 \% \mathrm{Pd}, 40 \mathrm{mg}$, Degussa) and ammonium formate $(1.55 \mathrm{~g}, 24.5$ $\mathrm{mmol})$ were suspended in methanol $(10 \mathrm{~mL})$ and at room temperature the crude oil dissolved in methanol $(2 \mathrm{~mL})$ was added dropwise. The reaction mixture was stirred for $3 \mathrm{~h}$ at room temperature and $5 \mathrm{~h}$ at $40{ }^{\circ} \mathrm{C}$. The catalyst was removed by filtration and the filtrate was evaporated in vacuo. The crude product was purified by column chromatography on silica gel eluted with dichloromethane/methanol/ $\mathrm{NEt}_{3}(3: 1: 0.1)$ to give 33 (435 $\mathrm{mg}, 1.37 \mathrm{mmol}$ ) asa colorless solid. Final purification and removal of salts were accomplished by HPLC under RP conditions: HPLC-column Luna-C18, 150 x $25 \mathrm{~mm}, 5 \mu \mathrm{m}$ particle size. Eluent A: water. Eluent B: acetonitrile; flow rate: $14 \mathrm{ml} /$ minute; UV detection wavelength: $210 \mathrm{~nm}$.

Analytical HPLC: modified reversed phase method: column: Waters Symmetry C18, 150x 3mm, $5 \mu \mathrm{m}$ particle size. Eluent A: 0.1\% TFA in water. Eluent B: water/acetonitrile/TFA 100:900:0.75 (v/v/v). Flow rate: $0.8 \mathrm{ml} /$ minute. UV detection wavelength: 210 and $269 \mathrm{~nm}$. Injection volume: $10 \mu$ l. Sample solvent: eluent A. Column temperature: $20^{\circ} \mathrm{C}$. Sampler temperature: $15^{\circ} \mathrm{C}$. Gradient profile: $0 \mathrm{~min} / 1 \%$ eluent B, $10 \mathrm{~min} / 1 \%$ eluent B, $15 \mathrm{~min} / 15 \%$ eluent B, $20 \mathrm{~min} / 99 \%$ eluent B, $21 \mathrm{~min} / 99 \%$ eluent B, $22 \mathrm{~min} / 1 \%$ eluent B, $27 \mathrm{~min} / 1 \%$ eluent B. HILIC-method:

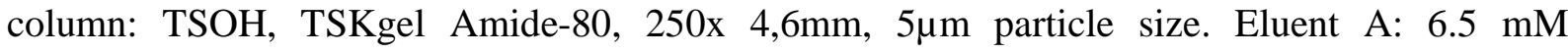


ammonium acetate in water / acetonitrile 900:100. Eluent B: acetonitrile. Flow rate: $1 \mathrm{ml} / \mathrm{minute}$. UV detection wavelength: 210 and $269 \mathrm{~nm}$. Injection volume: $10 \mu \mathrm{l}$. Sample solvent: acetonitrile/water $1: 1$ (v:v). Column temperature: $30{ }^{\circ} \mathrm{C}$. Sampler temperature: $20{ }^{\circ} \mathrm{C}$. Gradient profile: $0 \mathrm{~min} / 100 \%$ eluent B, $20 \mathrm{~min} / 75 \%$ eluent B, $25 \mathrm{~min} / 0 \%$ eluent B, $26 \mathrm{~min} / 100 \%$ eluent B, $30 \mathrm{~min} / 100 \%$ eluent B. ${ }^{1} \mathrm{H}-\mathrm{NMR}\left(500 \mathrm{MHz}, \mathrm{DMSO}-d_{6}\right): \delta=1.40-1.47(\mathrm{~m}, 2 \mathrm{H}), 1.72-1.75$ $(\mathrm{m}, 1 \mathrm{H}), 1.80-1.84(\mathrm{~m}, 1 \mathrm{H}), 2.75-2.81(\mathrm{~m}, 2 \mathrm{H}), 3.19-3.30(\mathrm{~m}, 2 \mathrm{H}), 3.81(\mathrm{~s}, 3 \mathrm{H}), 4.66(\mathrm{~d}, J=6$ $\mathrm{Hz}, 1 \mathrm{H}), 5.18$ (br s, 1H, OH), $6.95(\mathrm{dd}, J=7.8,3.9 \mathrm{~Hz}, 1 \mathrm{H}), 7.02(\mathrm{dd}, J=7.8,1.6 \mathrm{~Hz}, 1 \mathrm{H}), 7.43$ $(\mathrm{dd}, J=7.9,1.6 \mathrm{~Hz}, 1 \mathrm{H}), 8.25(\mathrm{~s}, 1 \mathrm{H}) \mathrm{ppm} ;{ }^{13} \mathrm{C}-\mathrm{NMR}\left(75 \mathrm{MHz}, \mathrm{DMSO}-d_{6}\right): \delta=24.12,25.12$, 43.17, 50.97, 52.77, 60.46, 69.15, 119.88, 121.23, 122.40, 136.86, 145.84, 147.38 ppm; MS $\left(\mathrm{ESI}^{+}\right) \mathrm{m} / z(\%): 318\left[\mathrm{M}+\mathrm{H}^{+}\right](100)$; HRMS $\left(\mathrm{ESI}^{+}\right): \mathrm{m} / z=340.0832$ [calc. for $\mathrm{C}_{13} \mathrm{H}_{19} \mathrm{NO}_{6} \mathrm{~S}+\mathrm{Na}$ : $340.0831]$.

$\begin{array}{ll}\text { Glossary } & \\ \text { Ac } & \text { Acetyl, } \\ \text { DBU } & \text { 1,8-Diazabicyclo[5.4.0]undec-7-ene } \\ \text { DMAP } & \text { Dimethylaminopyridine } \\ \text { EDC } & \text { 1-Ethyl-3-(3-dimethylaminopropyl)carbodiimid } \\ \text { HATU } & \text { 2-(7-Aza-1H-benzotriazole-1-yl)-1,1,3,3-tetramethyluronium hexafluoro-phosphate } \\ \text { HOBT } & \text { 1-Hydroxybenzotriazole } \\ \text { NMM } & \text { N-Methyl-morpholine } \\ \text { SGLT } & \text { Sodium dependent Glucose transport } \\ \text { TEMPO } & \text { 2,2,6,6-Tetramethylpiperidin-1-yl)oxyl } \\ \text { Oxon } & \text { Potassium peroxymonosulfate } \\ \text { TBDPS } & \text { tert-Butyl-diphenylsilyl } \\ \text { TBDMS } & \text { tert-Butyl-dimethylsilyl } \\ \text { TIPS } & \text { Triisopropylsilyl } \\ \text { TFA } & \text { Trifluoroacetic acid } \\ \text { TEA } & \text { triethylamine }\end{array}$

\section{Acknowledgements}

We want to thank Dr. Sabine Boisnard (Sanofi, ICMS Chilly-Mazarin) for providing information and support during development of the synthesis for 1- $\beta$-O-acyl glucuronide of AVE0897 7, Reiner Simonis, Sylvia Weber and Thorsten Fey for synthesis support and Dr. Witold Subotkowski (Sanofi, Chemical Development Bridgewater, NJ) for providing synthesis precursors. Our special thanks to Gerald Scholz, Claudia Loewe, Dr. Christian Klaus and Andreas Weilbächer for analytical support. Furthermore we would like to thank Dr. Joseph Schofield for critical discussions and corrections of this manuscript. 


\section{References}

1. King, R. S. In Drug Metabolism Handbook: Concepts and Applications; Nassar, A. F.; Hollenberg, P. F.; Scatina, J. Eds., John: Hoboken, 2009, pp 3-38.

2. Dudda, A.; Kürzel, G.-U. In Drug Discovery and Evaluation Safety and Pharmacokinetic Assays; Vogel, H.; Hock F.; Maas, J.; Mayer, D. Eds.; Springer: Berlin, Heidelberg, New York, 2006, pp 151-193.

3. Baillie, T. A.; Cayen, M. N.; Fouda, H.; Gerson, R. J.; Green, J. D. ; Grossman, S. J.; Klunk, L. J.; LeBlanc, B.; Perkins, D. G.; Shipley, L. A.; Toxicol. Appl. Pharmacol. 2002, 182, 188.

4. Shipkova, M.; Armstrong, V. W.; Oellerich, M.; Wieland, E. Ther. Drug. Monit. 2003, 25, 1.

5. US Department of Health and Human Services, Food and Drug Administration Guidance for Industry, Safety Testing of Drug Metabolites, 2008.

6. (a) Nedderman, A. N. R. Biopharm. Drug Dispos. 2009, 30, 153-162. (b) Humphreys, W. G.; Unger, S. E. Chem. Res. Toxicol. 2006, 19, 1564. (c) Prakash, C.; Shaffer, C.L.; Nedderman A. Mass. Spectrom. Rev. 2007, 26, 340.

7. Robison, T. W.; Jacobs; Future Science Bioanalysis, 2009, 1, 1193. (b) Nedderman, A. N. R.; Wright, P. Bioanalysis 2010, 2, 1235. (b) Baillie, T. A.; Chem. Res. Toxicol. 2009, 22, 263.(c) Smith, D. A.; Obach, R. S. Chem. Res. Toxicol. 2006, 19, 1570.

8. Davis-Bruno, K. L.; Atrakchi, A. Chem. Res. Toxicol. 2006, 19, 1561.(b) Smith, D. A.; Obach, R. S. Drug. Metab. Dispos. 2005, 33, 1409.

9. Walker, D.; Brady, J.; Dalvie, D.; Davis, J.; Dowty, M.; Duncan, J. N.; Nedderman, A.; Obach, R. S.; Wright P. Chem. Res. Toxicol. 2009, 22, 1653.

10. H. Atrakchi, A. K. Chem. Res. Toxicol. 2009, 22, 12170.

11. Luffer-Atlas, D. Drug. Metab. Rev. 2008, 40, 447.

12. Drăgon, C.-A.; Buchheit, D.; Bischoff, D.; Ebener, T.; Bureik, M. Drug Metab. Dispos. 2010, 38, 509.

13. Zöllner, A.; Buchheit, D.; Mayer, M. R.; Maurer, H. H.; Peters, F. T.; Bureik, M. Bioanalysis 2010, 2, 1277.

14. For review of glucuronidation methods and the preparation of the most common glucuronate glycosyl donors see Stachulski, A. V.; G. Jenkins, G. Natural Product Reports 1998, 173.

15. Regan, S. I.; Maggs, J. I.; Hammond, T. G.; Lambert, C.; Williams, D. P.; Park, B. K. Biopharm. Drug. Dispos. 2010, 31, 367.

16. Vanderhoeven, S. J.; Lindon, J. C.; Troke, J.; Tranter, G. E.; Wilson, I. D.; Nicholson, J. K. Xenobiotica, 2004, 34, 73.

17. (a) Mulder, G. J. Annu. Rev. Pharmacol. Toxicol. 1992, 32, 25. (b) Faed, M. E. Drug. Metab. Rev. 1984, 15, 1213. (c) Verbeeck, R. K. Drug Metab. Dispos. 1982, 10, 87.

18. Stachulski, A. V.; Jenkins, G. N. Nat. Prod. Rep. 1997, 15, 173.

19. (a) Becker, R.; Barua, A. B.; Olson, J. A. Biochem. J. 1996, 25, 212. (b) Barua, A. B.; Olson, J. A. J. Lipid. Res. 1985, 26, 1277. 
20. Panfil, I.; Lehman, P. A.; Zimniak, P.; Ernst, B.; Franz, T.; Lester, R.; Radominska, A. Biochim. Biophys. Act. 1992, 1126, 221. (b) Smith III, A. B.; Hale, K. J.; Rivero, R. A. Tetrahedron Lett. 1986, 27, 5813.

21. Schmidt, R. R.; Grundler, G. Synthesis, 1981, 885. (b) Schmidt, R. R.; Ruecker, E. Tetrahedron Lett. 1980. 21, 1421.

22. De Mesmaker, A.; Hoffmann, P.; Ernst, B. Tetrahedron Lett. 1989, 30, 3773. (b) Bugianesi, R.; Shen, T. Y. Carbohydrate Res. 1971, 19, 179.

23. (a) Juteau, H.; Gareau, Y.; Labelle, M. Tetrahedron Lett. 1997, 38, 1481. (b) Kenny, J. R.; Maggs, J. L.; Meng, X.; Sinnott, D.; Clarke, S. E.; Park, B. K.; Stachulski, A. V. J. Med. Chem. 2004, 47, 2816.

24. Perrie, J. A.; Harding, J. R.; Holt, D. W.; Johnston, A.; Meath, P.; Stachulski, A. V. Org. Lett. 2005, 7, 2591.

25. Smith III, A. B.; Rivero, R. A.; Hale, K. J.; Vaccaro, H. A. J. Am. Chem. Soc. 1991, 113, 2092.

26. (a) Akin, A.; Curran T. T. Synth. Comm. 2005, 35, 1649. (b) Biesalski, H.-K.; Doepner, G.; Kunz, H.; Paust, J.; Liebigs. Ann. 1995, 717.

27. Baba, A.; Yoshioka, T. Org. Biomol. Chem. 2006, 4, 3303; see also (b) Kunz, H.; Kullmann, R.; Werning, P.; Zimmer, J. Tetrahedron Lett. 1992, 33, 1969.

28. Boisnard S., Sanofi, Chilly-Mazarin, personal note.

29. (a) Faed, E. M.; Drug. Metab. Rev. 1984, 15, 1213. (b) Rachmel, A.; Hazelton, G. A.; Yergey, A. L.; Liberato, D. I. Drug. Metab. Dispos. 1985, 13, 705.

30. Vogt, P. F.; Hansel, J.-G.; Miller, M. J. Tetrahedron Lett. 1991, 38, 2803.

31. (a) Malkinson, J. P.; Falconer, R. A.; Toth, I. J. Org. Chem. 2000, 65, 5249. (b) Fiandor, J.; Garcias-Lopez, M. T.; De Las Heras, F. G.; Mendez-Gastrillon, P. P. Synthesis, 1985, 1121.

32. Zemplén, G.; Pacsu, E. Ber. Dtsch. Chem. Ges. 1929, 62, 1613. (b) Agostan K.; Dobo, A.; Rako, J.; Keregyarto, J.; Szurmai, Z. Carbohydrate Res. 2001, 330, 183.

33. Seebach, D.; Hungerbühler, E.; Naef, R.; Schnurrenberger, P.; Weidmann, B.; Zuger, M.; Synthesis, 1982, 138.

34. Vlaho, J.; Snatzke, G. Liebigs Ann. Chem. 1983, 570.

35. Suzuki, T.; Mabuchi, K.; Fukazawa, N. Bioorg. Med Chem. Lett. 1999, 9, 659.

36. (a) Ciriminna, R.; Pagliaro M. Org. Process Res. Dev., 2010, 14, 245. (b) Fatiadi A. Synthesis 1987, 85. (c) Tojo G.; Fernández M., Oxidation of Alcohols to Aldehydes and Ketones, Springer Berlin, 2006, 1-97. (d) Trost B. M.; Fleming I.; Ley S. V. Ed., Comprehensive Organic Chemistry, Vol. 7 Oxidation, Pergamon Press: Oxford.

37. Derdau, V.; Bierer, L.; Kossenjans, M. WO 2006072334 ; USPTO 20080207882.

38. (a) Derdau, V.; Fey, T.; Atzrodt J. Tetrahedron 2010, 66, 1472. (b) Derdau, V.; Fey, T.; Atzrodt J. J. Label. Compd. Radiopharm. 2010, 53, 381.

39. Iyer, S. S,; Rele, S. M.; Baskaran, S.; Chaikof, E. L. Tetrahedron 2003, 59, 631.

40. Deng, S.; Yu, B.; Xie, J.; Hui, Y. J. Org. Chem. 1999, 64, 7265. 
41. Methyl 1-bromo-1-deoxy-2,3,4-tri-O-acetyl- $\alpha$-D-glucopyranuronate $\mathbf{2 b}$ was purchased from Fluka, the corresponding benzoyl and pivaloyl derivatives were prepared in three steps from D-glucuronolactone according to Ref. 34.

42. Bollenback, G. N.; Long, J. W.; Benjamin, D. G.; Lindquist, J. A. J. Am. Chem. Soc. 1955, 77, 3310 .

43. (a) Falany, C.S. In Methods in Pharmacology and Toxicology, Drug Metabolism and Transport: Molecular Methods and Mechanisms, 2005, Ed. L. Lash, Human Press: Totowa, New Jersey, 342-375. (b) Barron, D. Recent advances in polyphenol research 2008, 317358.

44. Barron, D.; Ibrahim, R.K. Zeitschrift fuer Naturforschung C: Journal of Biosciences 1988, 43, 625. (b) Shinkawa, T.; Nakajima, H.; Nishijima, K.; Yamasaki, F.; Kato, K.; Ohzawa, N.; Mizota, M. Eur. J. Pharm. 1992, 219, 217. (c) Burmeister, H. R.; Vesonder, R. F. Appl. Environ. Microbiol. 1990, 56, 3209.

45. Varadi, A.; Gergely, A.; Beni, S.; Jankovics, P.; Noszal, B.; Hosztafi, S. Eur. J. Pharm. Sci. 2011, 42, 65.

46. Ishizaki, M.; Yamada, M.; Watanabe, S.; Hoshino, O.; Nishitani, K.; Hayashida, M.; Tanaka, A.; Hara, H. Tetrahedron 2004, 60, 7973.

47. Beugelmans, R.; Bourdet, S.; Bigot, A.; Zhu, J. Tetrahedron Lett. 1994, 35, 4349.

48. Bernotas, R.; Brown, P.; Emmons, G.; King, C.-H. WO0105764, US6465490.

49. (a) Offord, S. J.; Wong, D. F.; Nyberg, S. J. Clin. Pharm. 1999, 17. (b) Marek, G. J.; Martin-Ruiz, R. A. A.; Artigas, F. Neuropsychopharmacology 2005, 30, 2205 . (c) Teegarden, B.R.; Al Shamma, H.; Xiong, Y. Curr. Top. Med. Chem. 2008, 8, 969.

50. Alpert, A. J., J. Chromatogr. A 1990, 499, 177.

51. Gilar, M.; Olivova, P.; Daly, A. E.; Gebler, J. C. Anal. Chem. 2005, 77, 6426.

52. McCalley, D. V. J. Chromatogr. A 2007, 1171, 46. 